ROCZNIK PRZEMYSKI t. 57

HISTORIA z.1 (26) 2021

BARTOSZ PODUBNY (Leżajsk)

orcid.org/0000-0002-9418-3842

\title{
STANISŁAW MAJERSKI I JEGO WKŁAD W LIKWIDACJĘ ZNISZCZEŃ SPOWODOWANYCH WIELKĄ WOJNĄ NA TERENIE GALICJI
}

\author{
Abstract \\ STANiStaw MAJERSKi AND HiS CONTRIBUTION TO REMOVing First World War \\ DESTRUCTION IN GALICIA
}

The author presents the so far unexplored scope of work of the architect from Przemyśl, Stanisław Majerski (1872-1926) regarding his employment at the National Headquarters for Economic Reconstruction of Galicia, branch in Przemyśl, during the First World War. The 1914-1915 warfare caused enormous destruction in Galicia, particularly in the Przemyśl region; after the hostilities had ceased, estimation of the losses and reconstruction began. Based on the materials from the National Archive in Kraków the article outlines Majerski's work at the construction branch in Przemyśl. Majerski's work on the reconstruction of destroyed churches in Gorlice, Nisko, Stara Sól, Tamanowice and Żurawica is discussed as well.

Keywords: Stanisław Majerski, Stanisław Pollak, First World War, reconstruction, Gorlice, Nisko, Stara Sól, Tamanowice, Żurawica

Słowa kluczowe: Stanisław Majerski, Stanisław Pollak, I wojna światowa, odbudowa, Gorlice, Nisko, Stara Sól, Tamanowice, Żurawica

Architekt Stanisław Majerski (1872-1926) był absolwentem Politechniki Lwowskiej, synem jednej ze znaczących postaci Przemyśla przełomu XIX i XX w. - rzeźbiarza Ferdynanda Majerskiego ${ }^{1}$. Swoją karierę rozpoczął w końcu lat 90. XIX w. we Lwowie, aby w 1902 r. przenieść się do rodzinnego miasta i, oprócz działalności architektoniczno-budowniczej, wspólnie z ojcem i bratem Tadeuszem prowadzić słynny warsztat rzeźbiarsko-kamieniarski. U progu I wojny światowej Majerski miał już ugruntowaną pozycję jako projektant szeregu budowli

${ }^{1}$ Szerzej o postaci Ferdynanda zob. B. Podubny, Majerski Ferdynand Gerard, [w:] Przemyski słownik biograficzny, t. 2, red. L. Fac, T. Pudłocki, A. Siciak, Przemyśl 2011, s. 66-74. 
tak w Przemyślu, jak i szerzej w Galicji. W szczególny sposób ułożyła się jego współpraca z ówczesnym biskupem przemyskim obrządku rzymsko-katolickiego Józefem Sebastianem Pelczarem, dla którego wykonał kilka znaczących realizacji (m.in. drugi etap restauracji katedry w Przemyślu, rozbudowa seminarium duchownego, budowa tzw. Małego Seminarium). Dobra współpraca z biskupem i kurią zaowocowała również szeregiem projektów kościołów, zlokalizowanych głównie na terenie ówczesnej diecezji przemyskiej. Dobrze układały się jego relacje także ze zgromadzeniami zakonnymi, jak również władzami przemyskiego kościoła greckokatolickiego ${ }^{2}$.

Do niedawna informacje na temat działalności Stanisława Majerskiego w czasie I wojny światowej były bardzo skąpe. Według relacji rodzinnych został on zmobilizowany i służył w wojsku Monarchii w oddziałach inżynieryjnych, w randze porucznika. Nie brał czynnego udziału w prowadzonych walkach ${ }^{3}$. Służbę wojskową potwierdza zdjęcie Stanisława wykonane na werandzie jego rodzinnego domu, na którym uśmiechnięty mężczyzna stoi w mundurze z szablą przy boku ${ }^{4}$.

W dotychczasowej literaturze odnotowano kilka projektów Majerskiego związanych z obudową kościołów. Było to niewiele jak na tak płodnego architekta. Jednym z tropów, który pomógł poszerzyć wiedzę na temat jego działalności w czasie I wojny światowej, był nieduży akapit z nekrologu architekta, pióra kolegi po fachu i ucznia Kazimierza Osińskiego. Pisze on w nim: „W czasie wojny b. Ekspozytura budowlana C.O.G. w Przemyślu powierzyła ś.p. Majerskiemu odbudowę zniszczonych osiedli w kilkunastu gminach powiatu przemyskiego oraz kościołów, kaplic, szkół i budynków miejskich" 5. Przeprowadzona kwerenda pozwoliła na wyodrębnienie do przebadania zespół C.K. Namiestnictwo Centrala Krajowa dla gospodarczej odbudowy Galicji we Lwowie, znajdujący się w Archiwum Narodowym w Krakowie. Przeanalizowanie znajdujących się w nim akt o charakterze sprawozdawczym czy płacowo-kadrowym dało możliwość przybliżenia kolejnego aspektu działalności Stanisława Majerskiego w czasie Wielkiej Wojny. Celem artykułu jest zatem przedstawienie zróżnicowanych form działalności zawodowej architekta, związanych z likwidacją szkód wojennych zarówno tych wykonanych w ramach pracy w Centrali Krajowej, jak i tych wykonywanych indywidualnie, jak odbudowa świątyń.

Jednym z pierwszych zadań jakie podjął architekt było szacowanie szkód wyrządzonych przez wojnę. Wynikało to zapewne z faktu, że już od 1905 r. posiadł

${ }^{2}$ B. Podubny, Majerski Stanistaw Kostka, [w:] Przemyski..., s. 74-82; B. Podubny, Majerski Stanistaw Kostka, [w:] Stownik biograficzny twórców oświaty i kultury XIX i XX wieku Polski potudniowo-wschodniej. Suplement, red. K. Szmyd, Rzeszów 2015, s. 91-93; B. Podubny, Majerscy dla katedry przemyskiej. Historia restauracji katedry przemyskiej obrzadku łacińskiego w kontekście działalności Ferdynanda i Stanisława Majerskich, Przemyśl 2020.

${ }^{3}$ B. Podubny, Majerski Stanistaw Kostka, [w:] Przemyski..., s. 75

${ }^{4}$ Archiwum autora, fotografia Stanisława Majerskiego w mundurze wojskowym (kopia ze zbiorów Stanisława Brunona Majerskiego, syna Stanisława Majerskiego).

${ }^{5}$ K. Osiński, Ś. p. Stanisław Majerski „Ziemia Przemyska” R. 12, 1926, nr 8, s. 2. 
uprawnienia rzeczoznawcy przemyskiego sądu do spraw nieruchomości ${ }^{6}$. Z relacji Heleny Jabłońskiej, która przeżyła ciężkie walk o twierdzę przemyską, prowadzonych w latach 1914-19157, wynika, że architekt wykonywał oszacowania szkód, jakich w wyniku działań wojennych doznały budynki w Przemyślu czy dworskie w jego okolicy (np. w Maćkowicach). Na ich podstawie właściciele mogli zwracać się do władz austriackich o odszkodowania poniesionych strat. Jeden z takich dokumentów architekt przygotował dla zniszczonych nieruchomości, którymi opiekowała się wspomniana Jabłońska. W ciągu tygodnia (od 12 do 18 sierpnia 1915 r.) Majerski sporządził dokument szacujący szkody na około $14000 \mathrm{~K}$, za co pobrał wynagrodzenie w wysokości $80 \mathrm{~K}$. Pełnomocniczka właścicieli budynków reklamowała u niego zbyt niską wycenę, nie uwzględniającą wszystkich zniszczeń. Architekt zaakceptował uwagi i miał poprawić przygotowany kosztorys. Niestety z tekstu nie wynika, którymi dokładnie budynkami się zajmował. Według przekazów Jabłońskiej Stanisław był jednym z nielicznych architektów/inżynierów którzy pozostali w twierdzy, a jako „poważna firma” był rozchwytywany przez poszkodowanych właścicieli przemyskich nieruchomości ${ }^{8}$. Na tym etapie badań nie są znane inne przykłady tego rodzaju działalności Majerskiego.

Praca architekta $\mathrm{w}$ omawianej materii przyjęła z czasem instytucjonalizowaną formę. Został on zatrudniony w urzędzie powołanym do odbudowy kraju. Należy nadmienić, że działania wojenne w czasie I wojny światowej doprowadziły do ogromnych zniszczeń na terenie Galicji, a ich poziom był jednym z największych w skali całej monarchii austro-węgierskiej. W 1918 r. Polskie Towarzystwo Politechniczne szacowało, że: ,zniszczeniu uległo: 820 kościołów, 1210 cerkwi, 2100 szkół, 75699 budynków miejskich, 288941 budynków mniejszej własności, 3800 budynków mieszkalnych większej własności, 16 tys. budynków gospodarczych większej własności. Łącznie przeszło 500 tys. budynków, czyli $1 / 3$ wszystkich istniejących przed wojną" " Ogrom strat spowodował, że sprawę ich odbudowy zamierzano rozwiązać w sposób systemowy, angażując w nią administrację państwową Monarchii. Wynikiem tych potrzeb było stworzenie w strukturach c.k. Namiestnictwa nowego urzędu, od którego oczekiwano, aby w sposób kompleksowy, a jednocześnie wieloaspektowy, zrealizował zadanie

${ }^{6}$ B. Podubny, Majerski Stanisław Kosta, [w:] Przemyski..., s. 75.

${ }^{7}$ Helena Jabłońska przyjechała do Przemyśla z Sanoka w sierpniu 1914 r. poproszona przez krewnych, aby w czasie nieobecności właścicieli administrowała ich nieruchomościami. Były to budynki należące do Kazimiery i Eugeniusza Grandowskich, a znajdujące się przy ul. Smolki nr 18, 20, 22, 24. Poszlakowo, dzięki dziennikowi pisanemu przez nią w Przemyślu w czasie wojny, możemy założyć, że już w sierpniu 1915 r. Majerski nie pełnił służby wojskowej. Zob. S. Stępień, Przedmowa, [w:] H. z Seifertów Jabłońska, Dziennik z oblężonego Przemyśla (1914-1915), oprac. S. Stępień, Przemyśl 2017, s. 56-58.

${ }^{8}$ H. z Seifertów Jabłońska, op. cit., s. 609-610, 614-615, 617

${ }^{9}$ Tomasz Kargol podaje także wyliczenia m.in. Namiestnictwa, Centrali Krajowej dla Gospodarczej Odbudowy Galicji, które różnią się z podanymi powyżej danymi, ale dalej są to liczby oscylujące pomiędzy 420 a 500 tys. zniszczonych budynków, T. Kargol, Odbudowa Galicji ze zniszczeń wojennych w latach 1914-1918, Kraków 2012, s. 29-30. 
podniesienia ze zgliszcz wojennych terenów Galicji ${ }^{10}$. W ten sposób na początku 1916 r., po pewnej stabilizacji na arenie wojennej, powstała Centrala Krajowa dla gospodarczej odbudowy Galicji (dalej CKgoG lub Centrala). Realną działalność Centrala z siedzibą w Krakowie rozpoczęła 3 czerwca, a stamtąd została przeniesiona do Lwowa ${ }^{11}$. Urząd ten, aby objąć swoją działalnością zróżnicowane tematycznie obszary zniszczeń, został podzielony na sześć sekcji: techniczną, rolniczą, przemysłową, bankową, leśną i administracyjną. Zagadnienie odbudowy obiektów budowlanych wchodziło w skład kompetencji Sekcji I technicznej ${ }^{12}$. Terenowy charakter prac Centrali wymusił rozwinięcie struktur tej sekcji urzędu o dodatkowe jednostki organizacyjne - ekspozytury budowlane. Ich zasięg obejmował w większości przypadków kilka powiatów, a ze względu na skalę zniszczeń obszar funkcjonowania ekspozytur w Przemyślu czy w Jarosławiu został zawężony do jednego powiatu. Działalność ekspozytury miała na celu w pierwszej kolejności rozpoznanie zakresu strat, a następnie odpowiadała za administracyjne i czysto techniczne kwestie związane z „odbudową wsi, miasteczek, miast, kościołów, szkół, folwarków, zakładów przemysłowych, warsztatów, uzdrowisk, studni, wodociągów, jak również ewidencję materiałów budowlanych i robotników wykwalifikowanych". Nie zajmowała się ona budynkami znajdującymi się w gestii państwa ${ }^{13}$. Szesnaście pierwszych ekspozytur, w tym przemyska, zostało powołanych już w pierwszych miesiącach funkcjonowania $\mathrm{CKgoG}^{14}$. Centrala funkcjonowała do 2 października 1918 r., kiedy to została przekształcona w Krajowy Urząd Odbudowy. Ten natomiast od listopada 1918 r. podlegał Tymczasowemu Komitetowi Rządzącemu we Lwowie ${ }^{15}$. Na czele ekspozytury stał kierownik, a obsada składała się z kilku pracowników o wykształceniu technicznym oraz szeregu pracowników o charakterze pomocniczym i administracyjnym ${ }^{16}$.

${ }^{10}$ Dochodzenie do powołania jednej instytucji było oczywiście etapowe. Procesowi ścierania się koncepcji na formę i kształt odbudowy wspomniany już T. Kargol poświęca jeden z podrozdziałów swojej publikacji. Ibidem, s. 51-70. Ten temat został omówiony również zaraz po odzyskaniu przez Rzeczpospolitą niepodległości w publikacji Zobrazowanie działalności Krajowego Urzędu Odbudowy za czasów austryackich. Cz. ogólna, Lwów 1919.

${ }^{11}$ T. Kargol, op. cit., s. 70, 98-99.

${ }^{12}$ Ibidem, s. 101.

${ }^{13}$ Ibidem, s. 106-107.

${ }^{14}$ Ibidem, s. 106; Zobrazowanie działalności Krajowego ..., s. 26.

${ }^{15}$ T. Kargol, op. cit., s. 99.

${ }^{16} \mathrm{~T}$. Kargol stwierdza, że ekspozytury liczyły po kilku pracowników. Jak sam zauważa na wstępie, w swoich badaniach pominął akta pracownicze znajdujące się w Archiwum Narodowe w Krakowie (dalej: ANK), C.K. Namiestnictwo Centrala Krajowa dla gospodarczej odbudowy Galicji we Lwowie (dalej: CKgoG), a swoje stwierdzenie oparł na wybranej ekspozyturze (i to w zasadzie nie wiadomo jakiej, ponieważ w tekście wymienia ekspozyturę w Jaśle, a przypis jej dotyczący odnosi się do jednostki zlokalizowanej w Jarosławiu) nie przeprowadzając pełnej analizy jej działalności. Tymczasem przykładowo w ekspozyturze w Łańcucie pracowało czternaście - szesnaście osób. Ibidem, s. 16, 106, ANK, CKgoG, sygn. 33, s. 684, s. 721-723. 
Szczególna była rola Majerskiego w procesie likwidacji szkód wojennych jako architekta mieszkającego w Przemyślu, ponieważ straty dotyczące zabudowy w dużej mierze dotknęły rejon środkowego biegu Sanu. Według danych z 1916 r. wojenny kataklizm na terenie Galicji najbardziej odczuł właśnie powiat przemyski. $\mathrm{Na}$ jego terenie zniszczeniu uległo ponad 22000 obiektów $^{17}$. Jednak nie tylko ten region został w tak dużym stopniu zdewastowany przez zbroją pożogę. Burzący, wojenny walec przejechał również po dużej części budynków powiatu jarosławskiego, tarnowskiego czy gorlickiego ${ }^{18}$.

Ze względu na wymienioną skalę szkód, Ekspozytura budowlana w Przemyślu była jedną z najbardziej rozbudowanych, do której kierowane były największe fundusze ${ }^{19}$. Na jej czele stał c.k. starszy radca budowlany Eustachy Pannenko. Pełnił on tę funkcję od lipca 1916 r. (ekspozytura, jak donosiła ówczesna przemyska prasa, miała rozpocząć działalność 15 lipca $^{20}$ ) do października 1918 roku ${ }^{21}$. Dzięki kontroli nadsańskiej jednostki przeprowadzonej w 1917 r. przez Centralę, zachował się dokładny wykaz jej pracowników oraz dane określające charakter ich pracy, wynagrodzenia, dodatki oraz miejsca pracy - ponieważ oprócz biura w stolicy powiatu, ekspozytura posiadała również magazyny materiałowe w Hermanowicach, Medyce, Niżankowicach i Żurawicy. Zachowując układ dokumentu i ,charakter służbowy”, po kierowniku byli kolejno wymienieni: Roman Tabiński (c.k. inżynier), Jan Wowkonowicz (c.k. inżynier), Józef hr. Łubieński (inżynier cywilny), Stanisław Majerski (inżynier cywilny), Józef Grabowski-Oksza (dypl. inżynier), Stanisław Szczepański (inżynier), Stanisław Pollak (inżynier), Marcin Kawecki (c.k. inspektor lasów państwowych), Kazimierz Czunko (pomocnik techniczny), a także wielu innych pomocników, pracowników administracyjnych, magazynierów, nadzorców robót oraz dwóch szoferów, co wskazywałoby, że biuro miało także swój samochód. W sumie w ekspozyturze przemyskiej w tym czasie zatrudnionych było 41 osób $^{22}$. O jej znaczeniu świadczy fakt, że w rzeczywistości

${ }^{17} \mathrm{CKgoG}$ podawała, że według ówczesnych wyliczeń na terenie powiatu przemyskiego zniszczeniu uległo 7246 budynków mieszkalnych i 14791 budynków gospodarczych, do dawało razem 22037 budynki. Trzeba zaznaczyć, że zestawienie to nie obejmowało zniszczonych dworów i folwarków oraz zakładów przemysłowych. Sprawozdanie C.K. Namiestnictwa Centrali Krajowej dla Gospodarczej Odbudowy Galicyi: za czas od czerwca 1916 do lutego 1917, Kraków 1917, s. 4; mapa nr 1 Ilość zniszczonych budynków w Galicji. Dane z 1916 r., [w:] T. Kargol, op. cit., bpgn.

${ }^{18} \mathrm{Na}$ terenie drugiego pod względem zniszczeń powiatu jarosławskiego destrukcji uległo łącznie 16032 budynków mieszkalnych i gospodarczych; o ok. 1/4 mniej niż we wspomnianym powiecie przemyskim. Sprawozdanie C.K. Namiestnictwa..., s. 4; T. Kargol, op. cit., s. 28.

${ }^{19}$ Zobrazowanie działalności Krajowego..., s. 26.

${ }^{20}$ „Echo Przemyskie” R. 21, 1916, nr 57, s. 3.

${ }^{21}$ Przez ponad kolejny miesiąc funkcjonowania Ekspozytury i całej instytucji jako CKgoG funkcję kierownika pełnił inż. Roman Tabiński. Pozostał nim nadal w ramach Krajowego Urzędu Odbudowy, a zastąpił go 1 czerwca 1921 r. inż. Henryk Smulikowski. „Ziemia Przemyska” R. 4, 1918, nr 1, s. 3, nr 29, s. 2; R. 7, 1921, nr 23, s. 2; Album Inżynierów i Techników w Polsce, t. 1, cz. 1 Politechnika Lwowska. Rys historyczny, informacje, Lwów 1932, s. 52.

${ }_{22}^{2}$ Wykaz personelu ekspozytury budowlanej C.O.G. w Przemyślu wedtug stanu z dnia 19 kwietnia 1917 r. ANK, CKgoG, sygn. 33, s. 884-889. 
odrodzonej Rzeczypospolitej już jako biuro Krajowego Urzędu Odbudowy była miejscem zjazdu delegatów wszystkich biur z Galicji23 .

Stanisław Pollak, zatrudniony w niej jako referent, pisał, że przemyskie biuro było podzielone na osiem sekcji, a na czele każdej stał inżynier (np. Majerski), któremu podlegali dozorcy budów ${ }^{24}$. Po rozpoczęciu pracy ekspozytury pierwszą czynnością jej pracowników było określenie rozmiarów szkód poczynionych przez wojnę. Dane te były zbierane w oparciu o rozbudowany formularz, w którym nie tylko opisywano rodzaj i skalę zniszczeń, ale również stan budynków/gospodarstwa sprzed wojny. Na podstawie tak opracowanych danych planowano działania biura na okres roku ${ }^{25}$. Ekspozytura swoją pracę rozpoczęła $\mathrm{z}$ jednej strony wspomnianą akcją szacunkową, a z drugiej strony od razu musiała zająć się działalnością budowlaną - na ukończenie czekały rozpoczęte już budowy kilku tysięcy stodół i stu kilkudziesięciu baraków mieszkalnych ${ }^{26}$.

Z posiadanych dokumentów wiemy, że Stanisław Majerski pracował w przemyskiej ekspozyturze budowlanej od sierpnia $1916 \mathrm{r}^{27}$, a ostatnia wzmianka o jego pracy w tym urzędzie pochodzi z marca 1918 r. ${ }^{28}$ Jeżeli założymy, jak już wspomniano, że instytucja powstała w lipcu 1916 r., a zakończyła swój etap działalności w listopadzie 1918 r., to architekt pracował w niej prawie od początku oraz przez dłuższy czas jej funkcjonowania, tj. w okresie $20 \mathrm{z} 29$ miesięcy. Taką informację mamy potwierdzoną w zachowanych dokumentach, co nie wyklucza, że mógł tam pracować dłużej.

$\mathrm{Z}$ racji posiadanego wykształcenia i uprawnień zawodowych zatrudniono go na posadzie architekta cywilnego, zresztą jedynego w tym urzędzie, z pensją brutto 400 koron miesięcznie (netto $387 \mathrm{~K} 83 \mathrm{~h})^{29}$. Dzięki zachowanym miesięcznym Dziennikom czynności pracowników ekspozytury możemy prześledzić pracę Majerskiego w tej instytucji oraz przedstawić, jakimi sprawami zajmował się jeden z jej kluczowych pracowników ${ }^{30}$.

Począwszy do sierpnia 1916 r. zauważamy, że była ona bardzo uciążliwa i polegała głównie na pracy w terenie. Przykładowo w tym miesiącu Majerski

${ }^{23}$ „Ziemia Przemyska” R. 5, 1919, nr 160, s. 1-2; nr 161, s. 1.

${ }^{24}$ Artykuł Pollaka był niejako podsumowaniem ponad rocznego okresu działalności przemyskiej ekspozytury. W kolejnych numerach „Odbudowy Kraju” ukazywały się fotografie ilustrujące jego tekst.

S. Pollak, Odbudowa wsi w powiecie przemyskim, „Odbudowa Kraju” R. 1, 1917, nr 5, s. 423-428.

${ }^{25}$ S. Pollak, op. cit., s. 423-424.

${ }^{26}$ Ibidem, s. 425.

${ }^{27} \mathrm{Na}$ podstawie wypłaconych zaliczek na podróże służbowe oraz Dziennika czynności inż. Stanisława Majerskiego za miesiąc sierpień 1916. ANK, CKgoG, sygn. 33, s. 881; ibidem, sygn. 34, s. 45.

${ }^{28}$ ANK, CKgoG, sygn. 34, s. 875.

${ }^{29}$ Wyższe pobory otrzymywał tylko kierownik Ekspozytury K. Pannenko (656 K), natomiast pensja inżynierska stanowiła $400 \mathrm{~K}$ - otrzymywali ją oprócz Majerskiego jeszcze czterej pracownicy. ANK, CKgoG, sygn. 33, s. 884; sygn. 60, bpgn.

${ }^{30}$ Zachowały się Dzienniki za miesiące sierpień-wrzesień i listopad-grudzień 1916, styczeń-czerwiec 1917 i styczeń 1918. Każdy dzień miesiąca był opisany: praca w biurze, wyjazd, na ile dni, jaka odległość z Przemyśla i z powrotem. ANK, CKgoG, sygn. 34. 
przepracował 28 dni (!), z których tylko 8 w biurze; przejechał 612 kilometrów. Architekt w tym czasie zajmował się miejscowościami leżącymi w większości W wschodniej części powiatu. W większości przypadków były to sprawy związane z kontrolą budowy stodół (Buców - ob. Ukraina [dalej: Ukr], Hureczko, Hurko, Medyka, Nakło, Poździacz - ob. Leszno, Przekopana ob. Przemyśl, Stubienko, Stubno, Szechynie [Ukr], Torki, Wilcza - ob. Przemyśl) ${ }^{31}$. Budowa budynków gospodarczych, mogących w przyszłości zapewnić magazynowanie płodów rolnych lub inwentarza, a na bieżąco zapewnić dach nad głową, była wówczas najpilniejszą potrzebą. CKgoK opracowała typowe projekty domów oraz budynków gospodarczych, które miały być pomocne w szybszej odbudowie zniszczonych wsi ${ }^{32}$. Nie mniej liczne przypadki wyjazdów architekta odnosiły się do pozostałej zniszczonej zabudowy miejscowości. Były delegacje, w których Majerski szacował szkody powstałe przy szkołach (Chałupki Medyckie, Gdeszyce [Ukr], Hureczko, Hurko, Kosienice, Medyka, Miżyniec [Ukr], Niżankowice [Ukr], Siedliska, Szechynie, Zrotowice [Ukr]), a także pojedyncze przypadki sprawdzania stanu budynków cerkiewnych (cerkiew w Drohojowie i w Krównikach) ${ }^{33}$.

Pod wrześniową datą pojawiają się inne miejscowości w południowo-zachodniej i południowo-wschodniej części powiatu, będące celem badania przez Stanisława Majerskiego szkód, które dotknęły budynki szkolne (Cisowa, Dusowce - ob. Niziny, Jaksmanice, Krasice, Krówniki, Łuczyce, Olszany, Walawa). Praca w biurze skupiała się wyłącznie na przygotowaniach do remontów domów i szkół. Cykliczne były podróże do Medyki, będące formą kontroli składu budowlanego ekspozytury znajdującego się w tej miejscowości. Kolejnym zadaniem architekta była kontrola zniszczeń budynków mieszkalnych (Buców, Nakło, Medyka, Poździacz, Stubno, Torki). W dalszym ciągu trwało szacowanie szkód przy budynkach cerkiewnych (cerkwie w Dusowcach, Walawie) $^{34}$.

Kolejne miesiące pracy Majerskiego w przemyskiej ekspozyturze były podobnie intensywne. Niekończące się, wydawać by się mogło, dni wyjazdów w teren były poświęcone nadzorowaniu budów budynków mieszkalnych, gospodarczych, a następnie odbiorom ukończonych prac. Ogrom zakresu wykonanej przez architekta pracy dobrze ilustruje opracowana mapa obejmująca ówczesny powiat przemyski. Zaznaczono na niej miejscowości, do których wyjeżdżał Majerski w celach służbowych. Następnie przy każdej z nich za pomocą opracowanych

${ }^{31}$ ANK, CKgoG, sygn. 34, s. 45-47.

${ }^{32}$ Tematyka dotycząca opracowania planów jak i same plany znajdują się w: ANK, CKgoG, sygn. 31; nie były to jednak dzieła Majerskiego.

${ }^{33} \mathrm{~W}$ tym momencie można odnotować, że w 2015 r. ukazała się publikacja omawiająca sytuację, w jakiej znalazła się greckokatolicka diecezja przemyska w czasie I wojny, w której jeden z rozdziałów opisuje zniszczenia i straty na terenie diecezji powstałe w wyniku działań wojennych. Jednak szkody materialne, jakie poniosły parochie, zostały w niej opisane w sposób bardzo syntetyczny. ANK, CKgoG, sygn. 34, s. 45-46; A. Szczupak, Greckokatolicka diecezja przemyska w latach I wojny światowej, Kraków 2015, s. 224-231.

${ }^{34}$ ANK, CKgoG, sygn. 34, s. 43-45. 
przez autora znaków wizualizowano rodzaje budynków, przy których pracował architekt. Należy przy tym zaznaczyć, że o ile oznaczenie np. plebani oznaczało pojedynczy budynek, tak w przypadkach domów czy stodół to były dziesiątki budynków danego rodzaju w jednej miejscowości. Dodatkowo wyróżniono Medykę jako miejsce składu budowlanego powierzonego Majerskiemu.

Praca odbywała się nieprzerwanie, bez względu na porę roku, podobnie wyglądało obciążenie wyjazdami w teren w miesiącach zimowych czy letnich.

Z ciekawszych prac można wymienić prowadzone przez architekta sprawy dotyczące odbudowy cerkwi w Pikulicach i Nehrybce, budynków należących do parafii greckokatolickiej w Olszanach i Śliwnicy oraz zabudowań folwarcznych krasiczyńskiej parafii rzymskokatolickiej w Reczpolu (styczeń 1917) ${ }^{35}$. Badane były szkody dotyczące obiektów szkolnych (Gdeszyce, Miżyniec, Sanoczany [Ukr]). W Krzywczy i Średniej były badane jednocześnie szkody przy szkołach i plebaniach (Krzywcza rzym.-kat., Średnia gr.-kat.) (grudzień 1916) ${ }^{36}$. Majerski wyjeżdżał dwa razy służbowo także poza obszar działania ekspozytury, jakim był powiat przemyski. Były to delegacje w sprawie pięciu folwarków należących do jednostki wojskowej ${ }^{37}$, położonych w Chodnowicach (ówczesny pow. przemyski, [Ukr]), Józefówce (miejscowość niezidentyfikowana, możliwe, że była to nazwa własna folwarku) oraz w miejscowościach powiatu mościckiego: Myślatyczach [Ukr], Złotkowicach [Ukr] oraz w Trzcieńcu [Ukr] $]^{38}$.

W Medyce, oprócz nadzoru nad składem budowlanym, prowadził również sprawę dotyczącą remontu plebanii parafii rzymskokatolickiej ${ }^{39}$. Oddelegowany był do naprawy plebanii greckokatolickiej w Bucowie oraz cerkwi w Pikulicach i Nehrybce. Wyjeżdżał również do Chałupek Medyckich w sprawie szkód wyrządzonych przy tamtejszej szkole (luty 1917 r.) $)^{40}$. Marzec 1917 r. był dla Majerskiego kolejnym miesiącem szczelnie wypełnionym pracą i obowiązkami, które się w dużej mierze były powtarzalne. Nowością były działania związane ze zniszczeniami, jakich doznała plebania gr.-kat. w Hermanowicach oraz wyjazdy do dworów w południowo-wschodniej części powiatu: w Popowicach-Dziewięczycach [Ukr], Hermanowicach, Kniażycach, Kormanicach, Pikulicach, Popowicach [Ukr], Tyszkowicach [Ukr] ${ }^{41}$.

${ }^{35}$ Według byłego proboszcza krasiczyńskiego w Archiwum Archidiecezjalnym w Przemyślu powinien znajdować się Projekt odbudowy folwarku w Rzeczpolu z 1916 r. S. Bartmiński, Krasiczyn. Dzieje parafii i społeczności naszkicowane przez starego proboszcza, t. 1, Krasiczyn-Przemyśl 2010, s. 345-348, 352 .

${ }^{36}$ ANK, CKgoG, sygn. 34, s. 39-40.

${ }^{37}$ Autorowi nie udało się jej zidentyfikować.

${ }^{38}$ ANK, CKgoG, sygn. 34, s. 37-38.

${ }^{39}$ Kościół w Medyce przetrwał zawieruchę wojenną prawie nienaruszony (postrzał jedną kulą), natomiast bardzo zniszczone były budynki plebańskie: plebania i stodoła. Stajnia, spichlerz i wozownia zostały rozebrane i spalone. Archiwum Archidiecezji Przemyskiej (dalej: AAPrz), TDS II/1 Przemyski Zamiejski, Sprawozdanie o stanie i potrzebach parafii w Medyce (27.08.1915).

${ }^{40}$ ANK, CKgoG, sygn. 34, s. 35-36.

${ }^{41}$ ANK, CKgoG, sygn. 34, s. 33-34. 
Na podstawie zebranych informacji można wnioskować, że pierwszy okres działalności Majerskiego w strukturach przemyskiej ekspozytury i zapewne cała praca tego urzędu była zasadniczo skierowana na pomoc gospodarzom we wsiach we wznoszeniu budynków gospodarczych i domów. Kolejnym działaniem był zapewnienie bazy lokalowej dla szkół, później pomagano zasobniejszym właścicielom czyli parafiom, a następnie właścicielom zniszczonych majątków ziemskich ${ }^{42}$.

Na początku drugiego kwartału 1917 r. charakter prac nie uległ zmianie. Architekt kontynuował wyjazdy do Bucowa, Pikulic i Nehrybki. Musiał ponadto oszacować skalę uszkodzeń cerkwi w Sielcu (obecnie część Przemyśla). Badał również szkody wyrządzone przez działania wojenne wśród zabudowy parafii greckokatolickiej w Borszowicach [Ukr] i Dubiecku. W Hruszatycach Majerski skontrolował prace prowadzone przy spichlerzu i kuźni. Odbył delegację do Szechyni, która miała na celu zbadanie stanu budynku mieszkalnego wchodzącego w skład zespołu dworskiego. Natomiast w Bykowie [Ukr] nadzorował rozpoczęcie budowy plebani greckokatolickiej ${ }^{43}$.

Maj 1917 r. był dla architekta spokojniejszym okresem. Oprócz typowych spraw był dwa razy w Hurku (budowy dworskie i budowy domów), a w sprawach parafii greckokatolickiej odbył podróż do Bucowa (budowa plebanii), Korytnik, Walawy (brak informacji jakich dokładnie budynków dotyczyły) ${ }^{44}$. W czerwcu Majerski przebył w delegacjach rekordową odległość $794 \mathrm{~km}$. Skontrolował (najprawdopodobniej chodziło o odbiór zakończonych budów) 80 domów i 138 stodół. Wizytował także prace prowadzone przy budynkach szkół (Dusowce-ob. Niziny, Walawa, czy plebanii (Buców) ${ }^{45}$.

Niewiele zachowało się świadectw ówczesnych mieszkańców ziemi przemyskiej odnoszących się do działalności ekspozytury, a w szczególności architekta. Publikowana w „Ziemi Przemyskiej” w 1919 r. relacja z miejscowości Szechynie dowodzi, że niektóre jej aspekty budził kontrowersje u części społeczeństwa. Sprawa dotyczyła nieukończonego przed wybuchem wojny „Domu Polskiego” we wspomnianej miejscowości. Zniszczony budynek, pomimo kilkukrotnych interwencji u Majerskiego w latach 1916 i 1917, nie został przez niego zakwalifikowany do odbudowy ${ }^{46}$.

${ }^{42}$ Budowano nowe szkoły, ale gdy warunki temu nie sprzyjały, to stawiano zastępczy barak lub remontowano stary budynek. Podobnie czyniono w przypadku kościołów i cerkwi. S. Pollak, op. cit., s. 427.

${ }^{43}$ ANK, CKgoG, sygn. 34, s. 31-32.

${ }^{44}$ ANK, CKgoG, sygn. 34, s. 11-12.

${ }^{45}$ Niestety brakuje dalszych Dzienników z 1917 roku, ale w innych dokumentach potwierdzona była intensywna praca Majerskiego w kolejnych miesiącach: wrześniu, październiku, listopadzie, grudniu. ANK, CKgoG, sygn. 34, s. 13-14. Wykaz kosztów podróży pracowników ekspozytury za miesiąc wrzesień, październik, listopad, grudzień 1917 r. ANK, CKgoG, sygn. 34, s. 477, 631, 705, 769.

${ }^{46}$ Zarzucano architektowi, że „lepszym szczęściem u tego pana cieszyły się ruskie czytelnie, aniżeli polskie towarzystwa". Trudno odnieść się do przytoczonych zarzutów. Z dzisiejszego punktu widzenia można domniemywać tylko, że niedokończony budynek mógł mieć niższą wartość w procesie kwalifikowania do odbudowy. „Ziemia Przemyska” R. 5, 1919, nr 209, s. 3. 
Ostatni Dziennik... zachował się ze stycznia $1918 \mathrm{r} .{ }^{47} \mathrm{~W}$ tym miesiącu, porównując $\mathrm{z}$ rokiem wcześniejszym, architekt więcej czasu spędził w biurze ekspozytury. W czasie wyjazdów służbowych w dalszym ciągu zajmował się składem w Medyce oraz kontrolą budowanych domów na terenie powiatu, zniszczeniami wyrządzonymi w szkołach (Kosienice, Lipowica - ob. Przemyśl, Ujkowice) i plebanii (Kosienice). Prace trwały dalej w lutym i w marcu, z którego pochodzi ostatni dokument potwierdzający pracę Stanisława Majerskiego w przemyskiej ekspozyturze ${ }^{48}$.

Porównując Dzienniki Stanisława Majerskiego z pracującym z nim, wspomnianym już powyżej inż. Stanisławem Pollakiem ${ }^{49}$ zauważamy, że pierwszy z nich wypełniał swoje dokumenty w sposób lakoniczny i skrótowy. Więcej szczegółów na temat pracy wykonywanej przez urzędników ekspozytury w terenie dowiadujemy się ze sprawozdań Pollaka ${ }^{50}$. Do ich obowiązków należało na początku przeprowadzenie wizji określającej rozmiar szkód. Następnie wyznaczenie placu pod nową budowę, jej nadzór oraz odbiór po ich zakończeniu. Wydawali także asygnaty na materiał potrzebny do budowy oraz zarządzali powierzonymi sobie składami budowlanymi. Majerski obsługiwał skład ekspozytury w Medyce, natomiast Pollak skład w Hermanowicach. Obydwaj bardzo często wyjeżdżali w delegacje, przy czym Pollak zajmował się głównie budową domów i budynków gospodarczych, natomiast Majerski zajmował się również cerkwiami, zabudowaniami plebańskimi, dworsko-folwarcznymi i szkołami. Zróżnicowanie mogło wynikać z doświadczenia i wyższych kwalifikacji zawodowych Majerskiego.

Zachowane tak szczegółowe informacje dotyczące pracy bohatera niniejszych rozważań w ekspozyturze posłużyły do zestawienia w tabeli danych ilustrujących tę formę jego działalności. Jak można zauważyć, architekt wykonał tytaniczną pracę. W ciągu 12 miesięcy, z których posiadamy pełne dane, przez 10 miesięcy pracował w trybie ciągłym, bez jednego wolnego dnia w miesiącu. W sierpniu 1916 r. pracował 28 dni z 31, a w listopadzie tegoż roku pracował tylko 15 dni (może było to związane z jakąś chorobą Majerskiego).

\footnotetext{
${ }^{47}$ ANK, CKgoG, sygn. 34, s. 843-844.

${ }^{48}$ Wykaz kosztów podróży pracowników ekspozytury za miesiąc luty, marzec, ANK, CKgoG, sygn. 34, s. 875, 973-975.

${ }^{49}$ Wybór do porównania inż. Stanisława Pollaka spośród pracowników ekspozytury jest wyborem subiektywnym. Autor, badając twórczość Stanisława Majerskiego zauważył, że obaj panowie współpracowali ze sobą, stąd też zainteresowanie tą postacią. Osoba Pollaka, pomimo że była ważną dla Przemyśla okresu międzywojennego, nie została jeszcze opracowana. Lektura zawężona do kilkunastu roczników „Ziemi Przemyskiej” daje nam obraz architekta, który oprócz prac wykonanych wspólnie z Majerskim, zaprojektował wykonany Dom Żołnierza Polskiego w Przemyślu, ale był także prezesem Towarzystwa Politechnicznego w Przemyślu, udzielał się czynnie w Towarzystwie Szkoły Ludowej, był członkiem zarządu Przemyskiego Klubu Sportowego Polonia, a w 1928 r. został odznaczony Złotym Krzyżem Zasługi. „Ziemia Przemyska” R. 8, 1922, nr 21, s. 3; R. 11, 1925, nr 19, s. 2-3; R. 12, 1926, nr 2, s. 3; R. 14, 1928, nr 48, s. 6; R. 14, 1928, nr 50, s. 5.

${ }^{50}$ ANK, CKgoG, sygn. 34, s. 263-283.
} 
Tabela 1. Praca Stanisława Majerskiego w c.k. Namiestnictwa Centrali Krajowej dla gospodarczej odbudowy Galicji we Lwowie w ekspozyturze budowlanej w Przemyślu za okres sierpień 1916 - czerwiec 1917 (bez października) oraz styczeń - luty 1918.

\begin{tabular}{|c|c|c|c|c|c|c|}
\hline Rok & miesiąc & $\begin{array}{c}\text { Liczba } \\
\text { dni } \\
\text { miesiąca }\end{array}$ & $\begin{array}{c}\text { Liczba dni } \\
\text { przepraco- } \\
\text { wanych }\end{array}$ & $\begin{array}{c}\text { Liczba } \\
\text { dni } \\
\text { w biurze }\end{array}$ & $\begin{array}{c}\text { Liczba } \\
\text { dni w dele- } \\
\text { gacjach }\end{array}$ & $\begin{array}{c}\text { Przeje- } \\
\text { chane } \\
\text { km }\end{array}$ \\
\hline 1916 & sierpień & 31 & 28 & 8 & 20 & 612 \\
\hline 1916 & wrzesień & 30 & 30 & 11 & 20 & 664 \\
\hline 1916 & październik & b.d. & b.d. & b.d. & b.d. & b.d. \\
\hline 1916 & listopad & 30 & 15 (nie pracował & 4 & 11 & 374 \\
\hline 1916 & grudzień & 31 & 31 & 10 & 20 & 722 \\
\hline 1917 & styczeń & 31 & 31 & 10 & 20 & 659 \\
\hline 1917 & luty & 28 & 28 & 12 & 16 & 424 \\
\hline 1917 & marzec & 31 & 31 & 8 & 23 & 769 \\
\hline 1917 & kwiecień & 30 & 30 & 12 & 18 & 620 \\
\hline 1917 & maj & 31 & 31 & 16 & 15 & 454 \\
\hline 1917 & czerwiec & 30 & 30 & 8 & 22 & 794 \\
\hline 1917 & lipiec-grudzień & b.d. & b.d. & b.d. & b.d. & b.d. \\
\hline 1918 & styczeń & 31 & 31 & 18 & 13 & b.d. \\
\hline 1918 & luty & 28 & 28 & 11 & 17 & b.d. \\
\hline
\end{tabular}

Opracowanie własne autora na podstawie: ANK, CKgoG, sygn. 34

W ciągu tych dziesięciu i pół miesiąca, z których mamy pełne dane na temat delegacji Majerskiego, architekt przejechał 5494 km, co na miesiąc daje średnią około $523 \mathrm{~km}$, a trzeba podkreślić, że mówimy o terenach bardzo mocno zniszczonych przez działania wojenne. Jak już wspomniano, w ekspozyturze byli zatrudnieni dwaj szoferzy, co wskazuje, że posiadała ona jakiś samochód lub samochody, ale biorąc pod uwagę liczbę pracowników, to pewnie nie byli oni w każdej delegacji wożeni własnym transportem.

Omówiona działalność Stanisława Majerskiego w ramach struktury przemyskiej ekspozytury oprócz cerkwi nie obejmowała poważniejszych realizacji, takich jak np. odbudowa niszczonych kościołów, rezydencji, a także budowli użyteczności publicznej. Prawdopodobnie Majerski wykonywał te bardziej prestiżowe realizacje prywatnie.

Niewiele wiemy o pracach przy dwóch ostatnich kategoriach budowli. Odnośnie rezydencji posiadamy informację, że już w 1915 r. architekt przygotował 
ofertę na wykonanie prac zabezpieczających uszkodzenia w zamku w Krasiczynie, która jednak nie została uwzględniona ${ }^{51}$. Więcej wiadomości zachowało się o pracach, które Majerski prowadził przy likwidacji szkód powstałych w świątyniach. Na terenie ówczesnej diecezji przemyskiej zniszczeniu lub dużym uszkodzeniom uległo kilkadziesiąt kościołów i kaplic. Już zniszczenia poczynione w 1914 r. spowodowały, że biskup przemyski Józef Sebastian Pelczar w pierwszych dniach stycznia $1915 \mathrm{r}$. zwracał się we Wiedniu osobiście do ministra Maximilina Hussarka o pomoc przy odbudowie kościołów. Natomiast początkiem $1915 \mathrm{r}$. ordynariusz wezwał duchowieństwo i wiernych diecezji do ofiar na rzecz zniszczonych świątyń, a kolejnych zeszytach „Kroniki Diecezji Przemyskiej" podawano już wykazy składek na budowę kościołów oraz odbudowę tych najbardziej zniszczonych ${ }^{52}$.

Pierwszą czynnością, którą należało wykonać, aby można wystąpić o finansowe wsparcie władz państwowych, było oszacowanie strat. Majerski, oprócz wiedzy, posiadał także uprawnienia $\mathrm{w}$ tej materii, stąd też został poproszony o kosztorys strat kościoła w Starej Soli [Ukr]. Ta pochodząca z lat 50. XVIII w. świątynia została zniszczona w czasie działań wojennych, prowadzonych w październiku lub listopadzie 1914 r. ${ }^{53}$ Znacznym uszkodzeniom uległa towarzysząca kościołowi kaplica, a także ściany i dach świątyni. Zdemolowane zostały również zabudowania plebańskie, zarówno mieszkalne, jak i gospodarcze. W 1915 r. po ustabilizowaniu się sytuacji na froncie, Majerski wykonał operat, według którego szkody przy kościele zostały wycenione na $75000 \mathrm{~K}$, natomiast pozostałych budynków na $50000 \mathrm{~K}$. Straty w inwentarzu żywym i martwym wyceniono na $180000 \mathrm{~K}^{54}$. Dwa lata później architekt został ponownie zaproszony do współpracy, tym razem w celu przygotowania projektu odbudowy kościoła ${ }^{55}$. Niestety nie podjęto wówczas

${ }^{51}$ Zamek został ostrzelany w czasie oblężenia Przemyśla. Uszkodzeniu uległ przede wszystkim hełm i latarnia kaplicy zamkowej oraz wieża bramna. Centralnyj Derżawnyj Istorycznyj Archiw Ukrainy m. Lwiw, fond 616, opis 1, sprawa 98; T. Szydłowski Die verheerungen des krieges an kunstdenkmälern in Galizen „Mitteilungen der K.K. Zentral-Kommission zur Erforschung und Erhaltung der Kunst- und Historischen Denkmale", Band 14, 1915, nr 10-11, s. 219-221; T. Szydłowski, Ruiny Polski: opis szkód wyrządzonych przez wojnę w dziedzinie zabytków sztuki na ziemiach Małopolski i Rusi Czerwonej z 227 rycinami i mapka orientacyjna, Warszawa, Kraków 1919, s. 79-85.

${ }^{52}$ Pelczar, dając przykład, wyłożył 10000 koron. „Kronika Diecezji Przemyskiej” (dalej: KDP) R. 15, 1915, z. 2, s. 4; Ibidem, z. 3, s. 20-21, 25; J. Kupczewska, Biskupa Józefa Sebastiana Pelczara „Mój życiorys", [w:] Święty Józef Sebastian Pelczar (1842-1924). Rektor Uniwersytetu Jagiellońskiego i biskup przemyski, red. A. Kubiś, J. Wołczański, Kraków 2005, „Studia do Dziejów Wydziału Teologicznego Uniwersytetu Jagiellońskiego", t. 17, s. 145.

${ }^{53}$ P. Krasny, Kościół parafialny p.w. Św. Michała Archanioła w Starej Soli, [w:] Materiaty do dziejów sztuki sakralnej na ziemiach wschodnich dawnej Rzeczypospolitej, red. J. K. Ostrowski, cz. 1 Kościoły i klasztory rzymskokatolickie dawnego województwa ruskiego (dalej MDDS), t. 5, Kraków 1997, s. 250-251.

${ }^{54}$ Centrala przyznała proboszczowi kredyt w wysokości $40000 \mathrm{~K}$ na usunięcie zniszczeń, z czego otrzymał 1/4 tej kwoty. ANK, Wydział Rewindykacyjny na b. zabór austriacki w Krakowie, sygn. 41.

${ }^{55}$ Lwiwska Naukowa Biblioteka Nacjonalnoj Akademii Nauk Ukrajiny im. W. Stefanyka, fond 26 Urząd Konserwatorski Województwa Lwowskiego, rkps 51, cz. 2, k. 236. 
prac, a ich realizacja została odłożona w czasie na początek lat 20. XX w., ale już według innych projektów ${ }^{56}$.

Bardzo ciężkie walki były prowadzone również na zachodnich krańcach diecezji przemyskiej. Mowa w tym przypadku o bitwie gorlickiej, która przyczyniła się do uszkodzeń kościołów w Łużnej, Moszczenicy czy obu kościołów w Sękowej ${ }^{57}$. Bardzo mocno ucierpiały Gorlice i górująca nad miastem świątynia. Była to wówczas relatywnie młoda budowla, ponieważ jej budowa rozpoczęła się 1876, a prace ukończono na początku lat 90. XIX w. Na miejscu starszego kościoła wybudowano trójnawową bazylikę o charakterystycznej wieży, postawionej przy południowej ścianie prezbiterium ${ }^{58}$. Świątynia, jak i towarzyszące jej zabudowania plebańskie, zostały zniszczone w wyniku ostrzału wojsk austriackich w styczniu i lutym 1915 r., które atakowały zajęte przez Rosjan miasto. Skala zniszczeń Gorlic i ich parafialnej świątyni odbiła się szerokim echem, między innymi w ówczesnej prasie ${ }^{59}$. Duże zainteresowanie spowodowało fotograficzne udokumentowanie zdemolowanego kościoła. Widzimy na nich, że ostrzał prowadzony był od południa i spowodował zniszczenie dachu nad nawą główną, zawalenie się prawie całego sklepienia nad nią (zachował się jeden gurt i szczątki sklepienia od strony prezbiterium). Oprócz wschodniego fragmentu $\mathrm{z}$ oknem, w większości nie istniała południowa ściana nawy głównej. Podobny los spotkał południową nawę boczną. Zawalił się także południowo-zachodni narożnik wieży. W niewielki stopniu ucierpiała fasada, w której widać jeden większy otwór po pocisku. Pomimo dużej skali zniszczeń ocalał wschodni masyw świątyni i nawa północna, dzięki czemu uniknęły destrukcji najważniejsze elementy wyposażenia ołtarz główny, oba boczne i ambona. Zniszczeniu uległy organy, witraże, ławki i inne drobne przedmioty ${ }^{60}$. Ogrom zniszczeń miasta spowodował, że jego stanem zainteresowane były najważniejsze osobistości w kraju ${ }^{61}$. Zrujnowane Gorlice i świątynię wizytowali m.in. namiestnik Galicji

\footnotetext{
${ }^{56}$ Prace projektowe powierzono Bronisławowi Wiktorowi i Mieczysławowi Koczurowi. P. Krasny, Kościót parafialny p.w. Św. Michała Archanioła w Starej Soli [w:] MDDS, t. 5, Kraków 1997, s. 251.

${ }^{57}$ KDP R. 17, 1917, z. 2, s. 45.

${ }^{58}$ B. Podubny, Kościót parafialny pw. Narodzenia NMP w Gorlicach, w: Corpus Vitrearum Polska. Witraże z lat 1800-1945 w kościołach rzymskokatolickich Metropolii Krakowskiej i Przemyskiej, http://cvp.baza-witrazy.uj.edu.pl/Detail/objects/1191 (dostęp: 23.03.2021).

${ }^{59}$ Kościół był ostrzelany czterokrotnie 16, 20, 21 stycznia i 8 lutego. Powstał album ilustrujący ogrom wyrządzonych szkód. Świątynia została na pewien czas zamknięta, a msze odprawiano w mieszkaniu ks. Swieykowskiego lub miejscowej ochronce. K. Ruszała, Wielka Wojna w małym mieście. Gorlice w latach 1914-1918, Kraków 2015, s. 60, 159-160; „Czas” R. 68, 1915, nr 345, s. 2; K. Irzykowski, Brama zwycięstwa. (Ciag dalszy) II. „Nowa Reforma”, R. 34, 1915, nr 436, s. 2.

${ }^{60}$ Narodowe Archiwum Cyfrowe, Koncern Ilustrowany Kurier Codzienny - Archiwum Ilustracji (dalej NAC, IKC), sygn. 3/1/0/9/1335/1 Fotografia „Gorlice. Zniszczony kościół Narodzenia Najświętszej Marii Panny”; NAC, IKC, sygn. 3/1/0/9/1335/2 Fotografia „Gorlice. Zniszczony kościół Narodzenia Najświętszej Marii Panny”; ibidem, sygn. 3/1/0/9/1341/1 Fotografia „Gorlice. Zniszczony kościół Narodzenia Najświętszej Marii Panny";

${ }^{61} \mathrm{~W}$ tym miejscu autor pragnie gorąco podziękować dr. Kamilowi Ruszale, który udostępnił materiały dotyczące odbudowy kościoła znajdujące się w wiedeńskim archiwum. Dzięki tym archiwaliom udało się doprecyzować wiele kwestii dotyczących historii świątyni i procesu jej odbudowy.
} 
Witold Korytowski, Stanisław Niezabitowski marszałek Sejmu Krajowego czy biskup krakowski Adam Sapieha ${ }^{62}$.

Już 21 maja 1915 r. na osobiste polecenie wiceprezydenta Namiestnictwa Stanisława Grodzickiego przybył do Gorlic c.k. starszy radca budownictwa Adam Topolnicki ${ }^{63}$. Miał on za zadanie zbadanie zniszczeń budynków państwowych oraz kościoła i plebanii. Po dokładnych oględzinach obu budowli Topolnicki stwierdził, że kościół można jeszcze odbudować, natomiast plebania się już do tego nie nadaje $^{64} .5$ czerwca przybył do miasta także Józef Sebastian Pelczar, ordynariusz diecezji przemyskiej, pod którego jurysdykcją znajdowała się miejscowa para$\mathrm{fia}^{65}$. Biskup osobiście zaangażował się w sprawę odbudowy gorlickiej świątyni. Wystosował pismo do namiestnictwa, kreśląc postulaty najpilniejszych działań. Według Pelczara, w pierwszej kolejności należało wybudować tymczasowy barak ${ }^{66}$, w którym można byłoby odprawiać nabożeństwa, równolegle uprzątnąć zniszczony kościół i przykryć budowlę, aby nie dopuścić do jej dalszej degradacji. Następnie jak najszybciej należało przystąpić do odbudowy całego zespołu kościelno-plebańskiego. Dzięki staraniom biskupa szybko, jeszcze w czerwcu, utworzono komitet parafialny, który miał się zająć odbudową kościoła. Na jego czele stanął ówczesny proboszcz gorlicki ks. Antoni Sos ${ }^{67}$.

27 czerwcu 1915 r. obradował komitet parafialny. Konkluzją tego posiedzenia było odstąpienie od zamiaru budowy tymczasowego baraku ze względu na koszty (około $26000 \mathrm{~K}$ ), gdyż i tak w przyszłości zostałby rozebrany, a pieniądze na jego budowę można spożytkować na remont północnej nawy kościoła. Drugą poruszoną kwestią było usunięcie gruzu oraz składowanie materiału, który można było jeszcze użyć oraz tymczasowe przykrycie świątyni. Ten zakres został wyceniony na niecałe $20000 \mathrm{~K}$ i o taką kwotę występował proboszcz do Ministerstwa Wyznań i Oświaty. Kolejną było wystosowanie prośby do rządu, aby z własnych środków sfinansował odbudowę kościoła, plebanii oraz stodoły. Komitet uchwalił

${ }^{62}$ Biskup Sapieha zainicjował powstanie w 1915 r. Książęco-Biskupiego Komitetu Pomocy dla Dotkniętych Klęską I Wojny Światowej, na rzecz którego łożył także biskup Pelczar. Österreichisches Staatsarchiv, Allgemeine Vervaltungsarchiv, Kultus, Neuer Kultus (dalej: ÖStA, AVA, NKult.), Signatur: AT-OeStA/AVA Kultus NK Kath Akten 621.1 (Pfarren in Galizien), Titel: Signatur 47: Go-Gw (dalej AT-OeStA/AVA Kultus NK Kath Akten 621.1, 47); J. Kupczewska, op. cit., s. 146, 148.

${ }^{63}$ Forma delegowania jak i stanowisko Topolnickiego, który był wówczas kierownikiem departamentu Xd Namiestnictwa świadczyły o poważnym, można rzec priorytetowym potraktowaniu kwestii obudowy miasta. A. Dziadzio, M. Mataniak, Namiestnictwo galicyjskie (1854-1914). Organizacja i zadania „Krakowskie Studia z Historii Państwa i Prawa” R. 2018, nr 11 (1), s. 160.

${ }^{64}$ ÖStA, AVA, NKult, AT-OeStA/AVA Kultus NK Kath Akten 621.1, 47.

${ }^{65}$ Sprawa musiał być dla biskupa ważna i pilna, ponieważ w ciągu jednego dnia samochodem majora Zbyszowskiego odbył podróż z Przemyśla do Gorlic i z powrotem. W dzisiejszych czasach podróż na tej trasie trwałaby około sześciu godzin, a trudno wyobrazić sobie ją w czasie wojny i biorąc pod uwagę ówczesny stan dróg i szybkość pojazdu. J. Kupczewska, op. cit., s. 147.

${ }^{66}$ Ta uwag była zapewne podyktowana doświadczeniami z okolic Przemyśla, gdzie przygotowując się do walk lub w ich trakcie zniszczono kościoły w całości, a wiejskie realia nie pozwalały na znalezienie tymczasowego lokum do sprawowania liturgii. J. Kupczewska, op. cit., s. 148, 154.

${ }^{67}$ ÖStA, AVA, NKult, AT-OeStA/AVA Kultus NK Kath Akten 621.1, 47. 
także zlecenie opracowania planów odbudowy i ich kosztorysów Stanisławowi Majerskiemu ${ }^{68}$.

Błyskawicznie, bo już na 3 lipca tego samego roku, architekt opracował inwentaryzację, plany i pięć kosztorysów (A-E) ${ }^{69}$. Obejmowały one kosztorys A- budowa prowizorycznego baraku kościelnego $(26000 \mathrm{~K})$; B - urządzenie prowizorycznego kościoła w północnej nawie kościoła (7 $305 \mathrm{~K} 30$ h); C - odbudowa świątyni wraz z wykonaniem zniszczonego wyposażenia (305 $541 \mathrm{~K} 56$ h); D - budowa nowej plebani $(86000 \mathrm{~K})$ i ostatni E - na wybudowanie nowej stodoły i wyremontowanie budynków gospodarczych (10 $100 \mathrm{~K})$. Zgodnie z uchwałą komitetu parafialnego odstąpiono o budowy prowizorycznego kościoła (Lit A). Razem koszt całości robót $(\mathrm{B}+\mathrm{C}+\mathrm{D}+\mathrm{E})$ wyniósł $408956 \mathrm{~K} 86 \mathrm{~h}$. Do tej kwoty dochodziło honorarium Majerskiego w wysokości $5819 \mathrm{~K} 84 \mathrm{~h}^{70}$.

Powyższa uchwała komitetu parafialnego rozpoczęła postępowanie, mające na celu uzyskanie finansowania ze środków rządowych, w tym szczególnie pilnej kwoty na zabezpieczenie kościoła i adaptację do kultu nawy północnej. Zgodnie z urzędową procedurą została ona przesłana do starostwa w Gorlicach, które pismem z dnia 9 lipca, popierając starania komitetu, przekazało sprawę prezydium namiestnictwa. Dalszym krokiem była opinia z 11 sierpnia 1915 r., przygotowana na rzecz Ministerstwa Wyznań i Oświaty przez departament architektury Xd namiestnictwa. Autorem opinii był jego kierownik, wspomniany Adam Topolnicki ${ }^{71}$. Potwierdził on zaproponowaną przez Majerskiego możliwość odbudowy kościoła, jak i konieczność budowy nowej plebani, zgodził się również z przyjętym

\footnotetext{
${ }^{68}$ Ibidem; natomiast należy podkreślić, że udział Majerskiego w odbudowie kościoła w Gorlicach jako pierwszy opisał K. Ruszała. Prace Majerskiego w Gorlicach nie są zaskoczeniem dla autora, ponieważ ks. Antoni Sos, który w 1899 r. objął probostwo gorlickie, u Stanisława Majerskiego zamówił projekty m.in. ołtarza bocznego, konfesjonałów, chóru muzycznego, balasek, które następnie zostały wykonane w pracowni jego ojca Ferdynanda. Niemniej istotnym tropem była wspomniana już współpraca architekta $\mathrm{z}$ biskupem Pelczarem, który osobiście zaangażował się w odbudowę gorlickiej świątyni. W tym samym roku co książka Ruszały ukazała się publikacja Andrzeja Ćmiecha, w której odbudowę przypisuje on Józefowi Gałęzowskiemu. Niestety ta część tekstu nie została opatrzona przypisem, dlatego trudno zweryfikować informację podaną przez autora. Jak wykazuję w dalszej części tekstu, nie zgadza się to jednak z datacją projektu Gałęzowskiego. K. Ruszała, op. cit., s. 161-162; Zbiory Dąbrowskich z Żołyni, S. Majerski, Gorlice. Projekty; A. Ćmiech, Gorlice dzieje miasta, Gorlice 2015, s. 140.

${ }^{69}$ Raczej niemożliwe jest, aby w tak krótkim czasie odbyć podróż z Przemyśla i wykonać tak czasochłonną dokumentację. Ponieważ Majerski wycenił budowę tymczasowego baraku (zgodnie z wizją Pelczara), z którego komitet zrezygnował na posiedzeniu 27 czerwca, wydaje się, że pojawił się w mieście po wizycie biskupa w Gorlicach i już wtedy rozpoczął prace nad projektami. Uchwała komitetu w kwestii wskazania projektanta była usankcjonowaniem już zastanej sytuacji, a została podjęta ze względów proceduralnych.

${ }^{70}$ Honorarium obejmowało wykonanie inwentaryzacji, planów, kosztorysów oraz koszty podróży do Gorlic wraz z pobytem. ÖStA, AVA, NKult, AT-OeStA/AVA Kultus NK Kath Akten 621.1, 47, Zdanie Departamentu architektury Xd c.k. Namiestnictwa (z 11.08.1915).

${ }^{71}$ Pierwotnie sprawa trafiła do Departamentu XIa, ale ponieważ Topolnicki był osobiście w Gorlicach, został poproszony o przedłożenie sprawozdania technicznego ze zniszczeń kościoła i plebanii w Gorlicach (niestety nieznane autorowi), a następnie o zaopiniowanie pisma komitetu parafialnego. Ibidem.
} 
kierunkiem działań, to jest w pierwszym etapie adaptacji nawy północnej na cele liturgiczne oraz zabezpieczenie przed destrukcją pozostałej substancji budowlanej kościoła. Przeanalizował przedstawione kosztorysy. Podsumowaniem była uwaga, żeby jak najszybciej przekazać komitetowi parafialnemu jednorazowy zasiłek w wysokości $100000 \mathrm{~K}$. Szybkość działania była konieczna, aby przed nadejściem zimy można było przystosować nawę północną oraz wykonać najpilniejsze prace przy kościele: wymurowanie ścian nawy bocznej, filarów i ściany południowej nawy głównej, filaru w narożniku wieży, wykonanie więźby dachowej i pokrycia z blachy nad nawą główną i boczną, zamontowanie rynien i rur spustowych. Należało także rozliczyć się z Majerskim. Całość proponowanych przez Topolnickiego działań zamknęła się kwotą $112351 \mathrm{~K} 33$ h. Skąd zatem proponowana kwota 100000 koron? Autor opinii uważał, że część budulca ze zniszczonych części kościoła i plebani (cegły, kamień, drewna i blachy) będzie nadawało się do ponownego wykorzystania. Odnośnie pozostałych postulatów formułowanych przez komitet na podstawie projektów przemyskiego architekta, uważał on, że mogą być finansowane w kolejnych latach, ale ostateczną decyzję pozostawiał swoim przełożonym ${ }^{72}$.

W lipcu 1915 r. oględziny zespołu kościelnego przeprowadziło miejscowe starostwo, a ich wynikiem było potwierdzenie stanowiska Topolnickiego, że nawa północna nie grozi zawaleniem. Zalecono natomiast, aby pozostałą część zniszczonych budynków plebańskich postanowiono odgrodzić przed dostępem osób postronnych ${ }^{73}$.

Nie oglądając się na wynik działań biurokratycznej machiny Monarchii, której działanie, pomimo uwag Topolnickiego o pilnym rozpoczęciu prac, było bardzo rozciągnięte w czasie, komitet parafialny rozpoczął prace przy kościele. Zgodnie z planami Majerskiego wykonano adaptację północnej nawy do sprawowania liturgii. Między lipcem a listopadem arkady międzynawowe zostały oszalowane deskami, a dla polepszenia doświetlenia w tymczasowych ścianach zamontowano wysokie pionowe okna ${ }^{74}$.

W pozyskiwanie środków dla zniszczonych kościołów zaangażował się, jak już wspomniano, biskup Pelczar. Wśród pierwszych funduszy, rozdysponowanych jeszcze w 1915 r., największe kwoty, to jest po $1000 \mathrm{~K}$, skierowano do trzech kościołów: w Radymnie, Laszkach Murowanych i Gorlicach ${ }^{75}$. Odbudowę wsparło

${ }^{72}$ Nie znamy oryginałów dokumentów porządzonych przez Majerskiego. O ich zakresie dowiedzieć się można z przytaczanej opinii Topolnickiego. Jako ciekawostkę można zauważyć, że ze względu na toczącą się wojnę Topolnicki pisał z Białej, ponieważ tam wówczas znajdowało się Namiestnictwo, a opinia była wysłana do Ministerstwa, które również zmieniło miejsce urzędowania i funkcjonowało w Belgradzie. Ibidem.

${ }^{73}$ K. Ruszała, op. cit., s. 161.

${ }^{74} 27$ listopada odbyła się w kościele msza poświęcona zmarłemu cesarzowi Franciszkowi Józefowi. „Nowa Reforma” R. 35, 1916, nr 1, s. 2; K. Ruszała, op. cit., s. 135; NAC, IKC, sygn. 3/1/0/9/1341/1 Fotografia „Gorlice. Zniszczony kościół Narodzenia Najświętszej Marii Panny”.

${ }^{75}$ „KDP” R. 15, 1915, z. 4, s. 48. 
także bractwo „Boni Pastoris”, które do końca 1916 r. przekazało sumę 5000 K, co było drugą pod względem wielkości dotacją przyznaną na budowane lub odbudowywane świątynie na terenie diecezji ${ }^{76}$.

Wracając do działań urzędów, starania komitetu powoli osiągały skutek. Ministerstwo Wyznań i Oświaty 27 października 1915 r. „w drodze łaski” przyznało parafii zaliczkowo $100000 \mathrm{~K}$ na działania, zgodne z opinią Topolnickiego. Namiestnictwo poinformowało o tym fakcie starostwo i komitet dopiero pismem z 14 grudnia 1915 r. Kolejnym krokiem było zebranie przez starostwo ofert na prace, co trwało kolejnych pięć miesięcy ${ }^{77}$. Zgłosiło się w sumie siedem firm, przy czym tylko cztery w wymaganym czasie. Był to architekt Henryk Zaremba ze Lwowa, architekt Józef Sosnowski ze Lwowa, firma Daniel Führinger ex Comp. budowniczy z Oświęcimia oraz inż. Jan Grzybiński z Podgórza. Najniższa ofertę złożył Grzybiński (144 $493 \mathrm{~K} 06$ h). Wyniki postępowania starostwo przesłało do namiestnictwa 22 maja $1916 \mathrm{r}$. Tam też po analizie ofert stwierdzono, że przedstawione oferty znacząco przekraczają kosztorysy z 1915 r. Postanowiono, że ze względu na wzrost około $50 \%$ kosztów budowy w stosunku do roku poprzedniego, zwrócić się ponownie do ministerstwa o zwiększenie dofinansowania, ponieważ kolejne zebranie ofert spowoduje kolejne zwiększenie kosztów odbudowy. Dzięki analizie korespondencji pomiędzy namiestnictwem a ministerstwem można wywnioskować także, że oprócz wspomnianych prac przy nawie północnej do 14 kwietnia 1916 r. parafia zdjęła dzwony z wieży. Niestety nie zapłacono do tej pory honorarium Majerskiemu, a w drodze negocjacji zgodził się on obniżyć je do 4000 K. Powyższe sprawy przestawiono ministerstwu dopiero w lipcu ze względu na niekompletność materiałów przesłanych przez starostwo. Kwestia odbudowy gorlickiego kościoła coraz bardziej oddalała się w czasie ${ }^{78}$.

Ministerstwo przychyliło się do prośby o zwiększenie kwoty dofinansowania, jednak dalej trwała korespondencja pomiędzy proboszczem, starostwem, namiestnictwem i ministerstwem. W marcu 1917 ks. Sos zwrócił się anulowanie oferty Grzybińskiego a wybranie oferty Zaremby, który międzyczasie zrównał ją kwotą

\footnotetext{
${ }^{76}$ Bractwo zrzeszało kapłanów diecezji przemyskiej, początkowo zajmowało się m.in. pomocą $\mathrm{w}$ organizacji misji na parafiach, $\mathrm{z}$ czasem również dofinansowaniem budowy i wyposażenia kościołów i kaplic. Na cele związane z odbudową i budową zniszczonych świątyń miało ono do dyspozycji na dotacje, oprócz wpływających składek, kwotę $56032 \mathrm{~K}$, przekazaną przez biskupa Pelczara, zebraną z okazji jubileuszu jego kapłaństwa. Wyższa kwotę, to jest $7000 \mathrm{~K}$, otrzymał kościół w Rozwadowie. „KDP” R. 16, 1916, z. 8-9-10, s. 110.

${ }^{77}$ Starostwo zamieściło w ówczesnej prasie ogłoszenie o rozprawie ofertowej na odbudowę kościoła parafialnego w Gorlicach z terminem do 1 maja 1916 r. oraz wadium w wysokości $5000 \mathrm{~K}$. „Głos Narodu” R. 26, 1916, nr 199, s. 7.

${ }^{78}$ Negocjacje w sprawie wynagrodzenia Majerskiego prowadziło c.k. Starostwo w Gorlicach, do którego stawił się architekt 23 maja 1916 r. Ostatecznie zgodził się na wspomniane 4000 z zaznaczeniem, że kwota zostanie zapłacona jego żonie Zofii, zamieszkałej w Przemyślu przy ul. Słowackiego L. 54, ponieważ on został powołany do służby wojskowej i jego adres nieustannie się zmienia. ÖStA, AVA, NKult, AT-OeStA/AVA Kultus NK Kath Akten 621.1, 47, Zdanie Departamentu architektury Xb c.k. Namiestnictwa (z 11.07.1916); Ibidem, Pismo Namiestnictwa do Ministerstwa Wyznań i Oświaty z 17 lipca 1916 r.
} 
przedstawioną przez konkurenta. Z zachowanej korespondencji wynika, że za Zarembą przemawiało także doświadczenie zawodowe (Grzybiński był urzędnikiem kolejowym) oraz zaplecze finansowe. Proboszcz uzyskał poparcie Namiestnictwa w powyższej materii, a następnie zgodę Ministerstwa ${ }^{79}$. Nie posiadamy jednoznacznej informacji, czy parafia gorlicka uzyskała przyznane jej fundusze na odbudowę, ani też dotyczącej rozwiązania sytuacji z wyborem wykonawcy ${ }^{80}$. Zubożenie na skutek wojny parafii jak i parafian, postępujący spadek wartości pieniądza, koniec wojny czy następnie odzyskanie przez Polskę niepodległości, te wszystkie czynniki miały prawdopodobnie wpływ na przeciągające się w czasie rozpoczęcie prac przy gorlickiej świątyni.

Obecny stan badań nie pozwala dokładnie ustalić czasu trwania odbudowy kościoła ${ }^{81}$. Wydaje się, że należy mówić o dwóch fazach odbudowy. Pierwsza, która dotyczyła podstawnych prac przy samej świątyni (odbudowa murów, sklepień i dachu) i druga obejmująca wieżę oraz wykończenie elewacji. Kościół został odbudowany zapewne w latach 1920-1921, a datę końcową wyznaczamy na podstawie sygnatury (1921), którą autor odczytał na witrażu św. Stanisława, umieszczonym w fasadzie gorlickiego kościoła ${ }^{82}$. Fakt fundowania witraży świadczy, że główne prace budowlane przy budowli musiały być ukończone ${ }^{83}$. Ten też zakres można wiązać $\mathrm{z}$ autorstwem Stanisława Majerskiego. Charakter prowadzonych prac był odtwórczy. Zachowana w dobrym stanie struktura architektoniczna, detal zewnętrzny jak i wewnętrzny warunkował pełne odtworzenie ścian, sklepień, detali czy dachu w pierwotnie zaprojektowanej formie.

Zakres wprowadzonych przez architekta zamian był delikatny. Głównie dotyczył formy sygnaturki. Wykonana w czasie budowy kościoła miała dość prostą i masywną

\footnotetext{
${ }^{79}$ Ibidem, Odpis zdania Departamentu tech. X b c.k. Namiestnictwa (7 VI 1917); Ibidem, Pismo z Ministerstwa Wyznań i Oświaty do Namiestnictwa w sprawie odbudowy kościoła parafialnego w Gorlicach (4 VIII 1917).

${ }^{80}$ Biorąc pod uwagę formalną akceptację ministerstwa można założyć, że pieniądze te zostały parafii przekazane. Przemawia też za tym fakt, że parafia w Gorlicach nie wykazała strat w czasie działań prowadzonych po odzyskaniu przez Rzeczpospolitą niepodległości, a mających na celu uzyskanie od Austrii odszkodowań za zniszczone kościoły m.in. diecezji przemyskiej. ANK, Wydział Rewindykacyjny na b. zabór austriacki w Krakowie, sygn. 13, 18.

${ }^{81}$ B. Podubny, Kościót parafialny..., passim.

${ }^{82}$ Monografista parafii ks. J. Wilk pisze, że kościół został odbudowany w 1. 1920-1924. Ustalenia tego autora należy traktować ostrożnie, ponieważ w innej części książki podaje, że było to w 1932 r. i niestety nie jest to jedyna niekonsekwencja ks. Wilka. Natomiast autorzy hasła Gorlice podają, że odbudowa była prowadzona w 1. 1920-1923, tymczasem wiadomo, że wieża jeszcze nie była dokończona. A. Ćmiech z kolei odbudowę datuje nieprzerwanie od 1920 do 1931 r. J. Wilk, Kościót parafialny w Gorlicach, Gorlice 2000, s. 33, 112; B. Lejman, T. Torbus, Gorlice, [w:] Zabytki Sztuki w Polsce, Małopolska, red. W. Bałus i D. Popp, Warszawa 2016, s. 395; A. Ćmiech, op. cit., s. 140.

${ }^{83}$ Odbudowa musiała być ogromnym wysiłkiem finansowym dla parafii. Z korespondencji pomiędzy miejscowym starostwem a tymczasowym zarządem miasta wynika, że władze angażowały się w zbiórkę żywności wśród miejscowych przedsiębiorców dla pracujących przy kościele robotników. Wynika też z nich też determinacja, aby w 1920 roku przekryć świątynię. Archiwum Państwowe w Rzeszowie Oddział w Sanoku, Akta miasta Gorlice (dalej: APS, AmG), sygn. 1024.
} 
formę wysokiej latarni, przekrytej kopulastym dachem z latarenką. Nowa sygnaturka była bardziej smukła, wysoka podstawa przechodziła w formę cebulastą, na której umieszczono latarnię przekrytą cebulastym hełmem ${ }^{84}$. Istotną nowością było otynkowanie ścian nawy głównej (zapewne na nawy boczne i prezbiterium zabrakło środków i zostały one otynkowane w późniejszym czasie). Oryginalnie kościół posiadał ceglane elewacje boczne, wieży i prezbiterium. Ta faktura ścian niestety nie mogła być utrzymana, ponieważ widoczne byłyby wstawki nowo przemurowanych fragmentów ścian. Kosmetyczną korektą była natomiast zmiana kształtów podziałów okien ${ }^{85}$.

Przyczyną niedokończenia prac było wyczerpanie funduszy na odbudowę. Już w 1922 r. parafia podjęła starania o organizację festynu czy indywidualnej zbiórki przez wyznaczone osoby, których zadaniem byłoby kwestowanie po miejscowościach w celu zbiórki pieniędzy na dalsze prace przy odbudowie kościoła ${ }^{86}$.

W ramach pierwszej fazy nie zdołano przeprowadzić odbudowy wieży. Na zdjęciu z 1929 r. widzimy, że jej górna część został rozebrana i następnie zabezpieczona deskowaniem i pulpitowym dachem ${ }^{87}$. Jej odbudował zajął się już inny architekt Józef Gałęzowski ${ }^{88}$. Finalnie też według projektu tego architekta powstała towarzysząca kościołowi plebania ${ }^{89}$.

Kolejną chronologicznie realizacją Stanisława Majerskiego był kościół w Tamanowicach [Ukr]. Budowla ta, znajdująca się wówczas w powiecie mościskim, została wybudowana w latach $1894-1895$. W czasie wojny została zamieniona na

${ }^{84} \mathrm{Na}$ podstawie pocztówek umieszczonych na stronie Gorlice i okolice na starej pocztówce http://www.widokowki.gorlice.pl/ (m.in. pocztówki „Gorlice. Ratusz i C.K.Poczta” (ok. 1900); „Gorlice. Kościół parafialny” (ok. 1930).

${ }^{85}$ NAC, IKC, sygn. 3/1/0/9/1285/1 Pocztówka ,Gorlice. Panorama miasta” (1915); ibidem, sygn. 3/1/0/9/1341/1 Fotografia „Gorlice. Zniszczony kościół Narodzenia Najświętszej Marii Panny”; ibidem, sygn. 3/1/0/9/1340/1 Fotografia „Gorlice. Zniszczony kościół Narodzenia Najświętszej Marii Panny”; ibidem, sygn. 3/1/0/9/1335/2 Fotografia „Gorlice. Zniszczony kościół Narodzenia Najświętszej Marii Panny".

${ }^{86}$ APS, AmG, sygn. 1044.

${ }^{87}$ Fotografia wykonana na okoliczność budowy mostu przedstawia na drugim planie panoramę miasta z kościołem oraz dokumentuje puste jeszcze miejsce przeznaczone na plebanię. NAC, IKC, sygn. 3/1/0/8/3372/1, fotografia „Most na Ropie w Gorlicach”.

${ }^{88} 25$ maja 1929 r. odbyła się konsekracja kościoła w Gorlicach. W tym samym roku zaproszono do współpracy przy dalszych pracach krakowskiego architekta Józefa Gałęzowskiego (1877-1963). Nie było możliwości kontynuacji prac przez Stanisława Majerskiego, ponieważ zmarł on nagle w 1926 r. wieku pięćdziesięciu czterech lat, a dwa lata wcześniej zmarł współpracujący z nim proboszcz ks. Sos. Zakres projektów Gałęzowskiego obejmował odbudowę wieży, niektóre detale architektoniczne elewacji oraz chór muzyczny. W styczniu 1931 r. tarnowska kuria (od 1925 r. parafia została wyłączona ze struktur diecezji przemyskiej) zaakceptowała projekt odbudowy wieży, po czym przystąpiono do prac. A. Laskowski, Odkrywanie „, ukrytego”. O witrażach gorlickiej fary, [w:] Witraże. Sztuka wciąż odkrywana, red. B. Fekecz- Tomaszewska, M. Ławicka, Kraków, Legnica 2020, s. 74; projekty J. Gałęzowskiego do kościoła w Gorlicach znajdują się w zbiorach Muzeum Narodowego w Krakowie.

${ }^{89}$ Wariantowe projekty plebanii J. Gałęzowskiego wykonane zostały w 1932 r. znajdują się również w zbiorach Muzeum Narodowego w Krakowie. 
szpital, a w czerwcu i lipcu 1915 r. spalona przez wojska rosyjskie ${ }^{90}$. Zapewne jeszcze przed końcem 1916 r. podjęto działania zabezpieczające kościół ${ }^{91}$. Właściwą odbudowę rozpoczęto w 1918 r., a wykonanie jej projektu powierzono Majerskiemu. W znacznym stopniu prace zabezpieczające świątynię był ukończone jeszcze w tym samym roku, ponieważ parafia zwróciła się do kurii przemyskiej z prośbą o konsekrację kościoła. Jednak konsekracja dokonana przez ks. Władysława Sarnę obyła się dopiero w 1922 r., po finalnym zakończeniu prac budowlanych ${ }^{92}$. W odbudową zaangażowało się między innymi bractwo „Boni Pastoris”, przekazując na ten cel do końca października 1919 r. kwotę $9800 \mathrm{~K}^{93}$. Prace prowadzone przez architekta przy świątyni w Tamanowicach nie były twórczą, artystyczną kreacją, która odcisnęłaby się na formie kościoła. Jak widzimy na reprodukcji fotografii z 1915 r. ${ }^{94}$, głównym zniszczeniem budynku było spalenie się więźby dachowej. Budowla nie utraciła nic ze swojej bryły, a porównanie reprodukcji z $1915 \mathrm{r}$. ze zdjęciem z $1992 \mathrm{r} \cdot{ }^{95}$ wskazuje, że prace przemyskiego architekta raczej ograniczyły się do odtworzenia zniszczonej substancji kościoła.

Kolejną świątynią, którą po pożodze wojennej ratował Majerski, był kościół położony na północnych rubieżach ówczesnej diecezji przemyskiej, we wsi Nisko (będącej jednocześnie siedzibą powiatu). Kościół w Nisku był ekspozyturą parafii Racławice, u progu wojny budowlą stosunkowo nową, ponieważ ukończoną w 1896 r. ${ }^{96}$ Ciężkie walki prowadzone w tym rejonie w latach $1914-1915$, kiedy front przechodził przez ten obszar trzykrotnie spowodowały ogromne straty ${ }^{97}$. W ich wyniku doszczętnie zostały zniszczone kościoły w Rudniku nad Sanem czy w Racławicach k. Niska, a inne świątynie, w tym niżańska, mocno uszkodzone ${ }^{98}$. Jak pisał Zygmunt Lasocki: „Nisko wraz z przysiółkami ma 334 domy spalonych. Kościół to ruina bez sklepień i dachu"99. Natomiast Adam Krasicki stwierdził,

${ }^{90}$ Kościół jako zniszczony został ogłoszony w sierpniowym zeszycie Kroniki z 1915 r., „,KDP” R. 15, 1915, z. 3, s. 25; Ibidem, R. 17, 1917, z. 2, s. 48; A. Betlej, Kościół parafialny p.w. Najświętszego Serca Pana Jezusa i kaplica grobowa Drohojowskich w Tamanowicach, [w:] MDDS t. 7, Kraków 1999, s. 344-345.

${ }^{91}$ Przemyskie bractwo „Boni Pastoris” w swoim sprawozdaniu z okres od lipca 1914 r. do końca 1916 r. odnotowało, że odbudowę kościoła w Tamanowicach wspomogło kwotą $3000 \mathrm{~K}$, która to dotacja była jedną z większych przyznanych w okresie sprawozdawczym. „KDP”, R. 16, 1916, z. 8-9-10, s. 109-110.

${ }^{92}$ A. Betlej, op. cit., s. 345.

${ }^{93}$ „KDP” R. 19, 1919, z. 8-12, s. 135, 140.

${ }^{94}$ Dotyczy to il. 500, która jest pomyłkowo podpisana jako stan z 1992 r. Właściwy podpis ilustracji znajduje się przy il. 499. A. Betlej, op. cit., bpgn.

${ }^{95}$ Il. 499, A. Betlej, op. cit., bpgn.

${ }^{96}$ „KDP” 1901, z. 10, s. 366.

${ }^{97} \mathrm{~T}$. Sudoł, Działania wojenne na ziemi rudnickiej i niżańskiej w czasie I wojny światowej, [w:] I wojna nad Sanem, red. A. Granaty, Stalowa Wola 2014, s. 67-71.

${ }^{98}$ KDP 1917, z. 2, s. 49; M. Florek, Zniszczenia okolic Niska i Rudnika nad Sanem w czasie Wielkiej Wojny 1914-1918, [w:] I wojna nad Sanem..., s. 81-82.

${ }^{99}$ Z. Lasocki, Powiat niżański po inwazji „Nowa Reforma” 1915, nr 420, s. 2 za: Relacje i opisy, wybór i oprac. M. Florek i A. Granaty, [w:] I wojna nad Sanem..., s. 164. 
że „Miasto Nisko [to] ruina kompletna, [...] kościół zupełnie rozwalony, bez dachu i wież” i dalej „Z kościoła tylko mury zewnętrzne, 36 granatów wpadło"100. Ogromne zniszczenie kościoła, którego odbudowa będzie bardzo kosztowna, potwierdza również „Kronika Diecezji Przemyskiej”101. Zniszczenia niżańskiej świątyni doskonale ilustruje zdjęcie zamieszczone w artykule Marka Florka, na którym widzimy budowlę pozbawioną prawie wszystkich dachów, a wieża istnieje wbrew przekazowi Krasickiego, ale brakuje jej hełmu. Na ścianach widoczne są ślady ostrzału, zniszczone są korony murów, a w górnym, północno-wschodnim narożniku transeptu, znajduje się duża wyrwa ${ }^{102}$. Plany odbudowy kościoła w Nisku Majerski przedstawił w 1919 r. i po ich zaakceptowaniu on też prowadził prace przy świątyni. Zostały one zakończone w 1922 r., a 19 marca dokonano poświęcenia świątyni i zaczęto odprawiać w niej nabożeństwa. Parafię czekało jeszcze kosztowne urządzenie kościoła. Na stan z 21 XII 1922 r. świątynia nie posiadała jeszcze wyposażenia ${ }^{103}$. Koszt całości prac komitet odbudowy pod kierunkiem miejscowego starosty Jana Dauksza oszacował na około $700000 \mathrm{~K}^{104}$. Ukończona świątynia została konsekrowana w 1928 r. przez sufragana przemyskiego biskupa Karola Józefa Fischera ${ }^{105}$.

W tym przypadku, w porównaniu z kościołem w Tamanowicach, zakres prac wykonanych przez Majerskiego był dużo większy. Analizując dokumentację ikonograficzną niżańskiej świątyni ${ }^{106}$ można stwierdzić, że na nowo został zaprojektowany wystrój elewacji prezbiterium, zwieńczenie oraz hełm wieży, pewnej modyfikacji poddano także garnitur dekoracji architektonicznej kościoła. W przypadku prezbiterium delikatnie został podwyższony dach, a wcześniejszy podział elewacji - ciąg naprzemiennych arkadowych blend i otworów okiennych - został zastąpiony przez dwa duże, półkoliście zakończone otwory okienne (od północy

\footnotetext{
${ }^{100}$ Za: M. Florek, op. cit., s. 82.

${ }^{101}$ Świątynia w Nisku, tak jak już wspomniana w Tamanowicach, znalazła się w zestawieniu najbardziej zniszczonych na terenie diecezji przemyskiej. Skala dewastacji spowodowała, że nabożeństwa odbywały się w wynajętej sali w budynku miejscowego Towarzystwa Gimnastycznego „Sokół”, a cały budynek został przeznaczony na cele sakralne. W kosztach wynajmu partycypowało bractwo „Boni Pastoris”, przeznaczając na ten cel 4000 K. AAPrz, TDS XXV/2 Rudnicki, Sprawozdanie z wizytacji dziekańskiej dokonanej w r. 1918 w dekanacie rudnickim; ,KDP” R. 15, 1915, z. 3, s. 25; R. 17, 1917, z. 2, s. 49; R. 19, 1919, z. 8-12, s. 140.

${ }^{102}$ M. Florek, op. cit., s. 88.

${ }^{103}$ Autorka publikacji o niżańskim kościele określiła architekta jako Majewskiego. Takie przekształcanie nazwiska niestety zdarza się tak w przypadku Stanisława, jak i jego ojca Ferdynanda. AAPrz, TDS XXV/2 Rudnicki, Sprawozdanie z wizytacji $w$ dekanacie rudnickim dokonanej $w r$. 1922; B. Bylinowska, Droga św. Józefa. Sanktuarium i parafia Św. Józefa w Nisku, Sandomierz 2003, s. 26-27.

${ }^{104}$ W „KDP” zamieszono apel o składanie ofiar na kościół w Nisku. W chwili jego ogłoszenia wierni zebrali 200 000; swój wkład miał również biskup Józef Sebastian Pelczar. „KDP” R. 19, 1919, z. 8-12, s. 192.

${ }^{105}$ AAPrz, TPS 118/1 Nisko Fara, bpgn.

${ }^{106}$ J. A. Barański, J. Ogiński, Nisko na starych pocztówkach, Stalowa Wola 2012, s. 24-25, 68-69; NAC, IKC, sygn. 3/1/0/9/4307/1 Fotografia „Nisko. Kościół parafialny”.
} 
i południa), wypełnione dekoracją maswerkową analogiczną do tej, którą Majerski zastał w otworach nawy. Od wschodu natomiast umieścił podobnych rozmiarów i kształtu blendę, mieszczącą obecnie krucyfiks. Duża zmiana dotyczyła nowego zwieńczenia wieży. Przed zniszczeniem przekrywał ją wysoki ostrosłupowy hełm, od frontu u podstawy dekorowany trójkątnym szczytem. Architekt zaokrąglił narożniki ostatniej kondygnacji wieży, a wieńczący ją gzyms został trójkątnie przełamany. Dzięki temu zabiegowi w zwieńczeniu wieży, z każdej strony można było umieścić tarcze zegarowe. Zasadnicza zmiana dotyczyła hełmu, który został znacznie obniżony, a narożniki jego połaci zostały ścięte. Nowy hełm zyskał także dekoracyjnie opracowany krzyż. Inaczej też Majerski zaprojektował tzw. sygnaturkę. W miejsce dawnej (ażurowa latarnia na ośmiobocznym cokole, przekryta cebulastym hełmem) zaproponował nową, bardziej nawiązującą do ukształtowania bryły niżańskiej świątyni - na czworobocznym, tak jak w wieży, cokole, umieścił cztery arkady, nad nimi wydatny gzyms, powyżej którego trójkątne szczyty. Całość przekrył hełmem z wieńczącym go krzyżem, nawiązującym do tych na wieży.

W czasie remontu i odbudowy kościoła w Nisku w pewnym stopniu uproszczono wystrój elewacji, rezygnując z remontu i likwidując płyciny dekorujące półfilary, likwidując wieńczące je kordonowe belkowanie, a wprowadzając na jego miejsce gzyms. Dodatkowo lizeny ponad pólfilarami pozbawiono dekorujących je niewielkich, ślepych eadicul. Ząbkowy fryz wieńczący elewacje oraz fryz arkadkowy w zwieńczeniu wieży, które pierwotnie były ceglane zostały otynkowane.

Projektując odbudowę kościoła w Nisku Stanisław Majerski uszanował zastaną kreację swego nieznanego obecnie poprzednika. Zaproponowane przez niego nowe formy zostały dobrze wkomponowane stylistycznie w architekturę kościoła. Natomiast rezygnacja z niektórych detali architektonicznych związana była zapewne, jak to najczęściej w takich przypadkach bywało, z zasobnością budżetu przewidzianego na prowadzone prace.

Najbliższą miejsca zamieszkania przemyskiego architekta była natomiast świątynia w Żurawicy. Powstała ona w latach 1888-1889 według rysunków Adolfa Kuhna, a budowę prowadził przemyski architekt Marceli Pilecki ${ }^{107}$. Kościół poświęcony został w 1889 r., ale jego konsekracja nastąpiła dopiero w 1905 r. Dokonał jej bp przemyski J. S. Pelczar ${ }^{108}$. W związku z tym, że budynek znajdował się na terenie twierdzy Przemyśl, a jego wieża stanowiła doskonały punkt obserwacyjny, wraz z rozpoczęciem Wielkiej Wojny została ona zajęta przez austriackie wojsko. Już we wrześniu 1914 r. wysadzili oni wieżę kościelną, aby nie mogła służyć wojskom nieprzyjaciela. Kolejny kataklizm nastąpiły rok później. Świątynia otrzymała ostrzał granatem w ścianę południową, zniszczeniu uległ dach oraz znajdujące

\footnotetext{
${ }^{107}$ E. Sawula, Historia budowy oraz wyposażenia wnętrza kościoła parafialnego p.w. Niepokalanego poczęcia NMP w Żurawicy, [w:] Dzieje Żurawicy. Studia i materiały t. 1, red. L. Fac, Żurawica 2010, s. 111-112, 114-115.

${ }^{108}$ Ibidem, s. 115-116.
} 
się w oknach witraże ${ }^{109}$. Pierwszy projekt na odbudowę wieży kościelnej Stanisław Majerski przygotował w 1921 r. Zakładał on na nowo wybudowanie górnej kondygnacji wieży, na planie kwadratu, przeprutej ostrołukowymi oknami. Nad otworami okiennymi zaplanował wimpergi, ponad którymi kondygnacja wieży lekko zwężała się dając podstawę pod przekrywający ją hełm. Był on założony na średniej wysokości cokole, iglicowy na planie kwadratu o ściętych narożnikach. Jego boki u podstawy zostały ozdobione niewielkimi wimpergami z motywem trójliścia. Podobny motyw zdobił podstawy czterech sterczyn flankujących w narożach hełm. Całość wieży wieńczyła otwarta korona i ustawiony nad nią krzyż ${ }^{110}$. Jednak z powodu rosnącej inflacji przy jednoczesnym braku funduszy i materiałów, wykonanie wieży zostało przesunięte na kolejny rok. $Z$ oszczędności zrezygnowano z pierwotnego projektu i architekt wykonał kolejny z uproszczoną formą wieży, która została zrealizowana. Budowę prowadził znany przemyski przedsiębiorca budowlany Józef Nikodemowicz ${ }^{11}$. Zrezygnowano z dodatkowej kondygnacji, a istniejącą przekryto ostrosłupowym hełmem, dekorowanym u podstawy czterema trójkątnymi szczycikami.

Zaangażowanie architekta w kwestie związane z odbudową nie zakończyły się bynajmniej wraz z odzyskaniem niepodległości i nie ograniczały się wyłącznie do wyżej opisanych działań. Paradoksalnie zakończenie wojny i odzyskanie przez Polskę niepodległości skomplikowały rozliczenia finansowe prac wykonanych przez zarówno przez architekta, jak i przedsiębiorców budowlanych z Przemyśla. Należności te w 1919 r. sięgały 8 milionów koron. Wśród poszkodowanych znalazł się także Majerski, który z grupą zainteresowanych udał się w maju 1919 r. do stolicy, aby - w szczególności u ministra skarbu - dochodzić swoich roszczeń. Według ówczesnych doniesień prasowych sprawa ta miała zakończyć się pozytywnie dla petentó $w^{112}$. Powyższa sprawa jest tylko promilem spraw, które wymagały regulacji pomiędzy Polską a dawnym zaborcą. Państwo polskie w okresie powojennym prowadziło szeroko zakrojoną akcję, mającą na celu zebranie informacji o skali zniszczeń kościołów, ich wartości oraz czy poszkodowani otrzymali zwrot ich kosztów od Austrii ${ }^{113}$.

Znane obecnie realizacje Stanisława Majerskiego, związane z naprawą zniszczonych świątyń, nie należały do wybitnych osiągnięć artystycznych. Majątki parafialne, tak jak i parafian, zostały mocno nadwyrężone przez wojnę. Dodatkowo

${ }^{109}$ Ocalało natomiast wnętrze kościoła zdobione m.in. polichromią Tadeusza Popiela, Ibidem, s. 118; „KDP” R. 17, 1917, z. 2, s. 44; „Kurier Lwowski” R. 35, 1917, nr 78, s. 1.

${ }^{110}$ Muzeum Narodowe Ziemi Przemyskiej, S. Majerski, Plan odbudowy wieży w Żurawicy 1921 r. MP-PA-108

${ }^{111}$ E. Sawula, op. cit., s. 119-120.

${ }^{112}$ Majerskiemu towarzyszyli inż. Stanisław Szczepański, przedsiębiorca budowlany Józef Nikodemowicz oraz właściciel pracowni malarskiej Marian Szpetkowski. W Warszawie uzyskali pomoc ze strony posłów ziemi przemyskiej ze Związku Narodowo-Ludowego Leonarda Tarnawskiego i Jana Godka oraz ks. Kazimierza Kotuli z PSL „Piast”. „Ziemia Przemyska” R. 5, 1919, nr 124, s. 2.

${ }^{113}$ ANK, Wydział Rewindykacyjny na b. zabór austriacki w Krakowie 
w okresie powojennym nastąpił wzrost cen. Oba te czynniki spowodowały, że odbudowy zniszczeń przeciągały się w czasie, a ich forma architektoniczna odzwierciedlała skromne możliwości finansowe zleceniodawców. W większości opisywanych przykładów architekt dostosowywał się do zastanej struktury architektonicznej. Wpisywał się w stan istniejący, a z powyższych względów upraszczał wystrój architektoniczny. Taką sytuację narzucała niejako forma podejmowanych działań w ramach odbudowy. Kształt zastanych rozwiązań z automatu narzucał kontynuację, a architekt z tym nie polemizował. Nowe rozwiązania stosował tam, gdzie istniejąca struktura nie wskazywała wprost kontynuacji. Tak było w przypadku sygnaturek na kościołach w Gorlicach i Nisku czy zwieńczenie wieży w Nisku i Żurawicy. Formy dachów czy też korona murów wież nie determinowały wyglądu ich kontynuacji. W tych fragmentach Majerski proponował własne rozwiązania architektoniczne.

Archiwum rodzinne Stanisława Majerskiego nie zachowało się, dlatego rekonstrukcja działalności architekta jest w dużym stopniu utrudniona ${ }^{114}$. Stąd też niewielka liczba znanych realizacji Majerskiego, dotycząca odbudowy kościołów i innych obiektów. Natomiast dość dobrze zachowany zespół archiwaliów dotyczący działalności $\mathrm{CKgoG}^{115}$ pozwolił na przybliżenie działalności Stanisława Majerskiego w czasie Wielkiej Wojny. Możemy zauważyć, że ciężką, bardzo intensywną pracą $\mathrm{w}$ przemyskiej ekspozyturze budowlanej w dużej mierze przyczynił się do poprawy warunków bytowych kilkuset rodzin z okolicznych miejscowości. Opis pracy jednego z pracowników przemyskiej ekspozytury daje nam pewien obraz działalności tego ważnego urzędu, który dotychczas nie był tak szczegółowo opisywany w literaturze. Wspomniany zespół archiwalny może jeszcze dostarczyć wielu informacji do opracowania działalności całej ekspozytury, ale również można w nim znaleźć informacje dotyczące działalności innych przemyskich architektów i inżynierów.

Postscriptum artykułu będzie projekt wykonany przez Stanisława Majerskiego na odbudowę kompleksu zabudowań folwarku w Hruszowicach. Architekt wykonał go w styczniu 1919 r. dla kapituły greckokatolickiego biskupstwa w Przemyślu, która była właścicielem majątku w tej miejscowości ${ }^{116}$. Nie posiadamy aktualnie informacji, czy Hruszewice zostały zniszczone w czasie Wielkiej Wojny, ale biorąc pod uwagę, że przez ten obszar przechodził front oraz sam tytuł projektu można przyjąć, że tak faktycznie było. Majerski w Hruszewicach zaprojektował zespół zabudowań mieszkalno-gospodarskich, wśród których skalą i rozwiązaniami

${ }^{114} \mathrm{~W}$ ostatnim czasie część spuścizny Stanisława i jego ojca Ferdynanda została odkryta w Zbiorach Dąbrowskich z Żołyni. Dotyczy ona głównie elementów wyposażeni kościołów, a projekty architektoniczne stanowią procent odkrytego zasobu. Autor uczestniczy w opracowaniu powyższego Zbioru. B. Podubny, Majerscy dla katedry przemyskiej, passim.

${ }^{115}$ Całość zespołu liczy 117 j.a., które zajmują 5 mb.

${ }^{116}$ Archiwum Państwowe w Przemyślu, Kapituła greckokatolicka, sygn. 284, k. 1-16. S. Majerski, Pomyst na odbudowanie folwarku w Hruszawicach. 
wyróżnia się dom mieszkalny dzierżawcy. Były przygotowane dwa warianty tego budynku, zróżnicowane wielkością oraz dekoracyjnością elewacji. Oba były budowlami drewnianymi i parterowymi. Większy dom zawierał w sobie sześć pomieszczeń oraz sień. Jego frontową elewację urozmaicała szeroka, otwarta weranda o konstrukcji słupowej. Elementy konstrukcyjne były dekoracyjnie profilowane, a szczyt dodatkowo ozdabiały motywy ćwierćsłoneczka. Natomiast w elewacji tylniej budynku znajdował się niewielki ganek. Całość budynku przekrywał wysoki, naczółkowy dach. Wersja skromniejsza domu dzierżawcy przewidywała budynek o czterech pomieszczeniach, którego bryłę wyróżniał centralny ryzalit w elewacji frontowej o szczycie dekorowanym słoneczkiem, a projektowany dach był półszczytowy. Dodatkowo Majerski zaprojektował skromne pod względem formy, utylitarne budynki: mieszkanie dla służby, komórki dla dzierżawcy, komórki dla służby, służbówkę wraz ze spichlerzem, spichlerz, stajnie dla krów i koni oraz osobne budynki dla tych zwierząt, stodołę oraz wozownię. W większości były to budynki drewniane, a tylko w przypadku spichlerza dolna, zgłębiona kondygnacja była murowana. Kwestia czy i w jakiej formie projektowane budynki zostały w Hruszewicach zrealizowane, jest jeszcze sprawą otwartą. Rozwiązania artystyczne, jakie zastosował Stanisław Majerski w przypadku projektu na dom dzierżawcy, odnoszą się z jednej strony do zakorzenionej już od ponad ćwierć wieku architektury w tzw. typie szwajcarskim (motyw rozbudowanej, otwartej, dekoracyjnie rozwiązanej werandy), a z drugiej są odzwierciedleniem aktualnych wówczas tendencji panujących w budownictwie drewnianym (bardzo popularny motyw słoneczka). Projekt budynków w Hruszewicach jest jednym z nielicznych znanych przykładów działalności Stanisława Majerskiego na polu architektury drewnianej. Stanowią także kolejny dowód działalności architekta, który w dużej mierze przyczynił się do odbudowy powiatu przemyskiego ze zniszczeń pożogi Wielkiej Wojny, a jego zaangażowanie twórcze w tej materii wykraczało również poza ten obszar.

Kończąc należy zauważyć, że niniejszy artykuł nie wyczerpuje w pełni omawianego zagadnienia. Jak już wspomniano, nieznane jest archiwum architektoniczne Stanisława Majerskiego. Doprecyzowania wymaga także jego działalność w zakresie odbudowy obiektów sakralnych, a szczególnie cerkwi. Niestety niesprzyjająca sytuacja epidemiczna, która odbija się na wielu dziedzinach życia codziennego, gospodarczego, wpływa również negatywnie na dostępności do archiwaliów i możliwości swobodnego przemieszczania się. Nie wykluczam także, że architekt prowadził jeszcze inne realizacje w zakresie omawianej tematyki, które w ramach poszerzania wiedzy o samych obiektach czy o działalności Majerskiego zostaną odkryte dalszym etapie badań. Niemniej jednak uważam, że przedstawiony materiał w znacznym stopniu ilustruje działalność Stanisława Majerskiego i jego zaangażowanie w odbudowę zniszczeń powstałych w wyniku I wojny światowej. 


\section{Bibliografia}

Źródla archiwalne:

Archiwum Archidiecezji Przemyskiej:

TPS 118/1 Nisko Fara, bpgn.

TDS II/1 Przemyski Zamiejski

TDS XXV/2 Rudnicki

Archiwum Narodowe w Krakowie:

C.K. Namiestnictwo Centrala Krajowa dla gospodarczej odbudowy Galicji we Lwowie, sygn. 31, $33,34,60$

Wydział Rewindykacyjny na b. zabór austriacki w Krakowie, sygn. 13, 18, 41

\section{Archiwum Państwowe w Przemyślu:}

Kapituła greckokatolicka, sygn. 284, S. Majerski, Pomyst na odbudowanie folwarku w Hruszawicach,

Archiwum Państwowe w Rzeszowie Oddział w Sanoku:

Akta miasta Gorlice, sygn. 1024, 1044

\section{Archiwum autora:}

Fotografia Stanisława Majerskiego w mundurze wojskowym (kopia ze zbiorów Stanisława Bruna Majerskiego, syna Stanisława Majerskiego)

Centralnyj Derżawnyj Istorycznyj Archiw Ukrainy m. Lwiw: fond 616 , opis 1 , sprawa 98.

Lwiwska Naukowa Biblioteka Nacjonalnoj Akademii Nauk Ukrajiny im. W. Stefanyka: fond 26 Urząd Konserwatorski Województwa Lwowskiego, rkps 51, cz. 2,

\section{Muzeum Narodowe w Krakowie:}

wykaz projektów J. Gałęzowskiego do kościoła i plebanii w Gorlicach

\section{Muzeum Narodowe Ziemi Przemyskiej:}

S. Majerski, Plan odbudowy wieży w Żurawicy 1921 r. MP-PA-108

\section{Narodowe Archiwum Cyfrowe:}

Koncern Ilustrowany Kurier Codzienny - Archiwum Ilustracji

sygn. 3/1/0/9/4307/1 Fotografia „Nisko. Kościół parafialny”

sygn. 3/1/0/9/1285/1 Pocztówka „Gorlice. Panorama miasta” (1915)

sygn. 3/1/0/9/1335/1 Fotografia „Gorlice. Zniszczony kościół Narodzenia Najświętszej Marii Panny” sygn. 3/1/0/9/1335/2 Fotografia „Gorlice. Zniszczony kościół Narodzenia Najświętszej Marii Panny” sygn. 3/1/0/9/1340/1 Fotografia "Gorlice. Zniszczony kościół Narodzenia Najświętszej Marii Panny” sygn. 3/1/0/9/1341/1 Fotografia "Gorlice. Zniszczony kościół Narodzenia Najświętszej Marii Panny” sygn. 3/1/0/8/3372/1 Fotografia „Most na Ropie w Gorlicach”

\section{Österreichisches Staatsarchiv, Allgemeine Vervaltungsarchiv:}

Kultus, Neuer Kultus, Signatur: AT-OeStA/AVA Kultus NK Kath Akten 621.1 (Pfarren in Galizien), Titel: Signatur 47: Go-Gw 
Zbiory Dąbrowskich z Żołyni:

S. Majerski, Gorlice. Projekty

Źródla drukowane:

Sprawozdanie C.K. Namiestnictwa Centrali Krajowej dla Gospodarczej Odbudowy Galicji za czas od czerwca 1916 do lutego 1917, Kraków 1917.

\section{Czasopisma:}

„Czas” 1915

„Echo Przemyskie” 1916

„Głos Narodu” 1916

„Kronika Diecezji Przemyskiej” 1901, 1915-1917, 1919

„Kurier Lwowski” 1917

„Nowa Reforma” 1916

„Ziemia Przemyska” 1918-1919, 1921-1922, 1925-1926, 1928

\section{Opracowania:}

Album Inżynierów i Techników w Polsce, t. 1, cz. 1 Politechnika Lwowska. Rys historyczny, informacje, Lwów 1932.

J. A. Barański, J. Ogiński, Nisko na starych pocztówkach, Stalowa Wola 2012.

S. Bartmiński, Krasiczyn. Dzieje parafii i społeczności naszkicowane przez starego proboszcza, t. 1, Krasiczyn-Przemyśl 2010.

A. Betlej, Kościót parafialny p.w. Najświętszego Serca Pana Jezusa i kaplica grobowa Drohojowskich w Tamanowicach, [w:] Materiały do dziejów sztuki sakralnej na ziemiach wschodnich dawnej Rzeczypospolitej, red. J. K. Ostrowski, cz. 1 Kościoły i klasztory rzymskokatolickie dawnego województwa ruskiego, t. 7, Kraków 1999, s. 343-350.

B. Bylinowska, Droga św. Józefa. Sanktuarium i parafia Św. Józefa w Nisku, Sandomierz 2003

A. Dziadzio, M. Matniak, Namiestnictwo galicyjskie (1854-1914). Organizacja i zadania „Krakowskie Studia z Historii Państwa i Prawa” R. 2018, nr 11 (1).

M. Florek, Zniszczenia okolic Niska i Rudnika nad Sanem w czasie Wielkiej Wojny 1914-1918, [w:] I wojna nad Sanem, red. A. Granaty, Stalowa Wola, 2014, s. 81-91.

A. Ćmiech, Gorlice dzieje miasta, Gorlice 2015.

K. Irzykowski, Brama zwycięstwa. (Ciag dalszy) II. „Nowa Reforma”, R. 34, 1915, nr 436, s. 2.

T. Kargol, Odbudowa Galicji ze zniszczeń wojennych w latach 1914-1918, Kraków 2012

P. Krasny, Kościót parafialny p.w. Św. Michała Archanioła w Starej Soli, [w:] Materiały do dziejów sztuki sakralnej na ziemiach wschodnich dawnej Rzeczypospolitej, red. J. K. Ostrowski, cz. 1, t. 5, Kraków 1997, s. 249-259.

J. Kupczewska, Biskupa Józefa Sebastiana Pelczara „,Mój życiorys”, [w:] Święty Józef Sebastian Pelczar (1842-1924). Rektor Uniwersytetu Jagiellońskiego i biskup przemyski, red. A. Kubiś, J. Wołczański, Kraków 2005, „Studia do Dziejów Wydziału Teologicznego Uniwersytetu Jagiellońskiego", t. 17, s. 21-206.

A. Laskowski, Odkrywanie „ukrytego”. O witrażach gorlickiej fary, [w:] Witraże. Sztuka wciąz odkrywana, red. B. Fekecz- Tomaszewska, M. Ławicka, Kraków, Legnica 2020, s. 69-88.

Z. Lasocki, Powiat niżański po inwazji, „Nowa Reforma” R. 34, 1915, nr 420, s. 2.

B. Lejman, T. Torbus, Gorlice, [w:] Zabytki Sztuki w Polsce, Małopolska, red. W. Bałus i D. Popp, Warszawa 2016, s. 395.

K. Osiński, Ś. p. Stanisław Majerski „Ziemia Przemyska” R. 12, 1926, nr 8, s. 2.

B. Podubny, Majerski Ferdynand Gerard, [w:] Przemyski słownik biograficzny, t. 2, red. L. Fac, T. Pudłocki, A. Siciak, Przemyśl 2011, s. 66-74. 
B. Podubny, Majerski Stanisław Kostka, [w:] Przemyski słownik biograficzny, t. 2, red. pod red. L. Fac, T. Pudłocki, A. Siciak, Przemyśl 2011, s. 74-82.

B. Podubny, Majerski Stanistaw Kostka, [w:] Stownik biograficzny twórców oświaty i kultury XIX i XX wieku Polski poludniowo-wschodniej. Suplement, red. K. Szmyd, Rzeszów 2015, s. 91-93.

B. Podubny, Majerscy dla katedry przemyskiej. Historia restauracji katedry przemyskiej obrzadku łacińskiego w kontekście działalności Ferdynanda i Stanisława Majerskich, Przemyśl 2020.

S. Pollak, Odbudowa wsi w powiecie przemyskim, „Odbudowa Kraju” R. 1, 1917, nr 5, s. 423-428.

K. Ruszała, Wielka Wojna w matym mieście. Gorlice w latach 1914-1918, Kraków 2015.

E. Sawula, Historia budowy oraz wyposażenia wnętrza kościoła parafialnego p.w. Niepokalanego poczęcia NMP w Żurawicy, [w:] Dzieje Żurawicy. Studia i materiaty, t. 1, red. L. Fac, Żurawica 2010, s. 105-126.

S. Stępień, Przedmowa, [w:] H. z Seifertów Jabłońska, Dziennik z oblężonego Przemyśla (1914-1915), oprac. S. Stępień, Przemyśl 2017, s. 7-68.

T. Sudoł, Działania wojenne na ziemi rudnickiej i niżańskiej w czasie I wojny światowej, [w:] I wojna nad Sanem, red. A. Granaty, Stalowa Wola 2014, s. 67-80.

T. Szydłowski Die verheerungen des krieges an kunstdenkmälern in Galizen „Mitteilungen der K.K. Zentral-Kommission zur Erforschung und Erhaltung der Kunst- und Historischen Denkmale", Band 14, 1915, nr 10-11, s. 217-224.

T. Szydłowski, Ruiny Polski: opis szkód wyrządzonych przez wojnę w dziedzinie zabytków sztuki na ziemiach Małopolski i Rusi Czerwonej z 227 rycinami i mapka orientacyjna, Warszawa, Kraków 1919.

A. Szczupak, Greckokatolicka diecezja przemyska w latach I wojny światowej, Kraków 2015.

Zobrazowanie działalności Krajowego Urzędu Odbudowy za czasów austryackich. Cz. ogólna., Lwów 1919.

J. Wilk, Kościót parafialny w Gorlicach, Gorlice 2000.

\section{Strony internetowe:}

B. Podubny, Kościót parafialny pw. Narodzenia NMP w Gorlicach, [w:] Corpus Vitrearum Polska. Witraże z lat 1800-1945 w kościołach rzymskokatolickich Metropolii Krakowskiej i Przemyskiej, http://cvp.baza-witrazy.uj.edu.pl/Detail/objects/1191 (dostęp: 23.03.2021)

Gorlice i okolice na starej pocztówce http://www.widokowki.gorlice.pl/ (m.in. pocztówki „Gorlice. Ratusz i C.K.Poczta” (ok. 1900); „Gorlice. Kościół parafialny” (ok. 1930). 


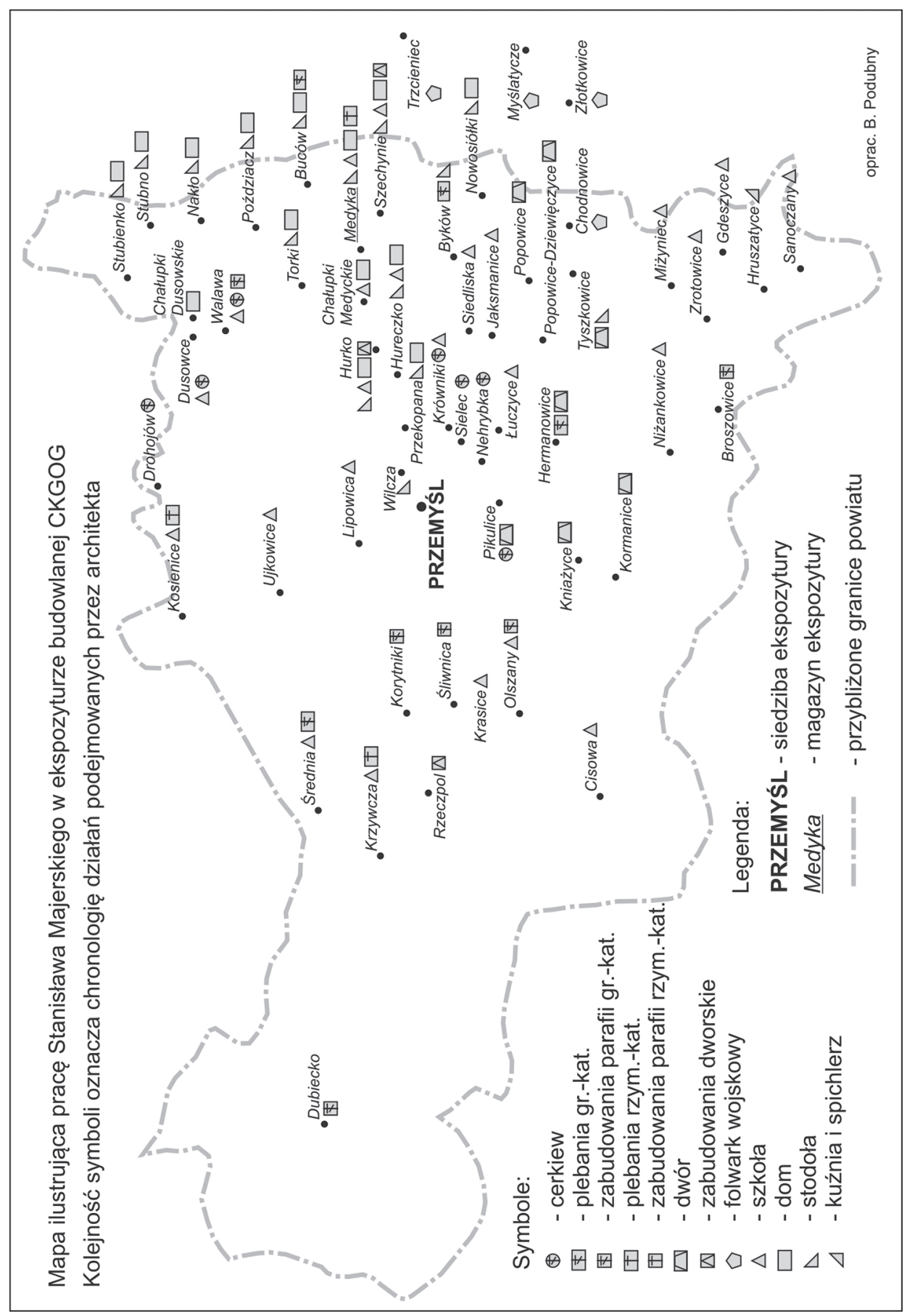




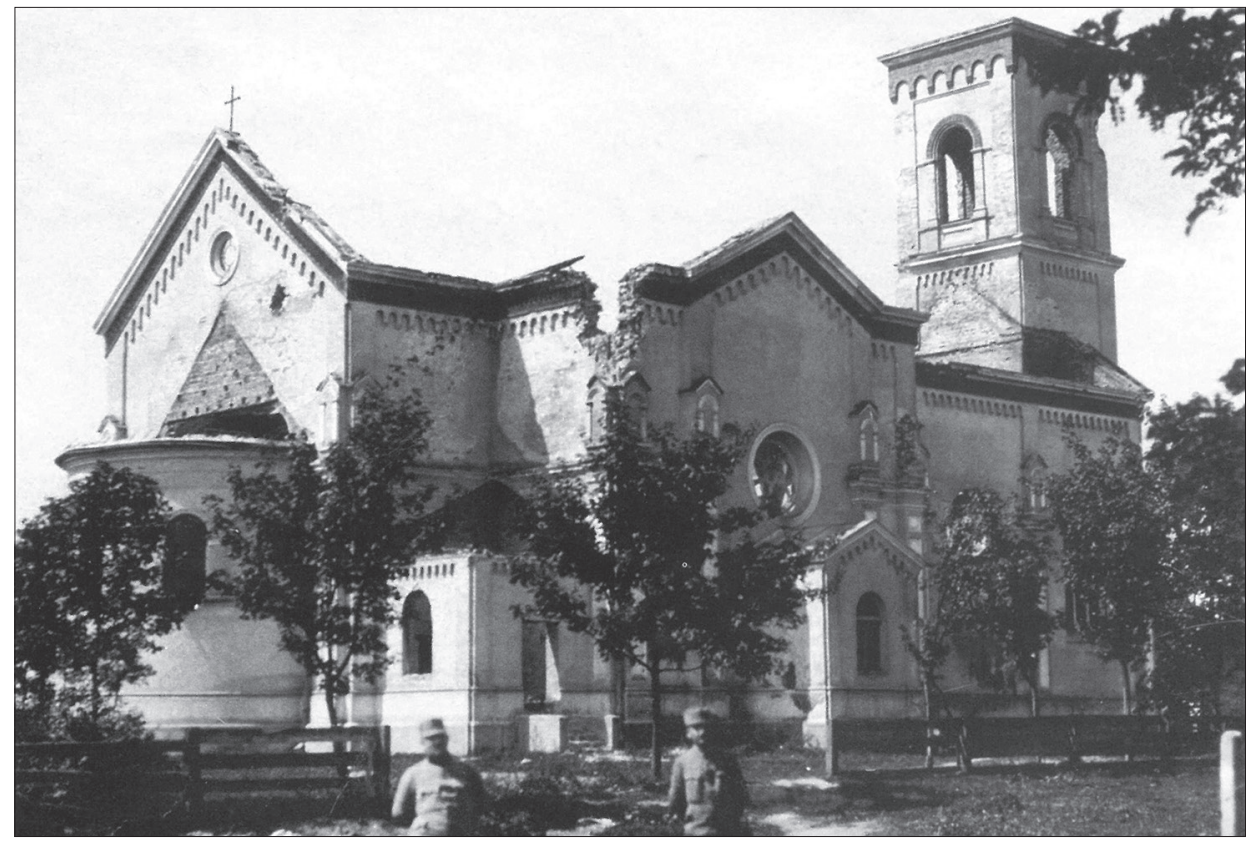

Nisko. Fragment zdjęcia z września 1915 r. ilustrujący zniszczenia kościoła pw. św. Józefa za Nisko na starych pocztówkach, Stalowa Wola 2012

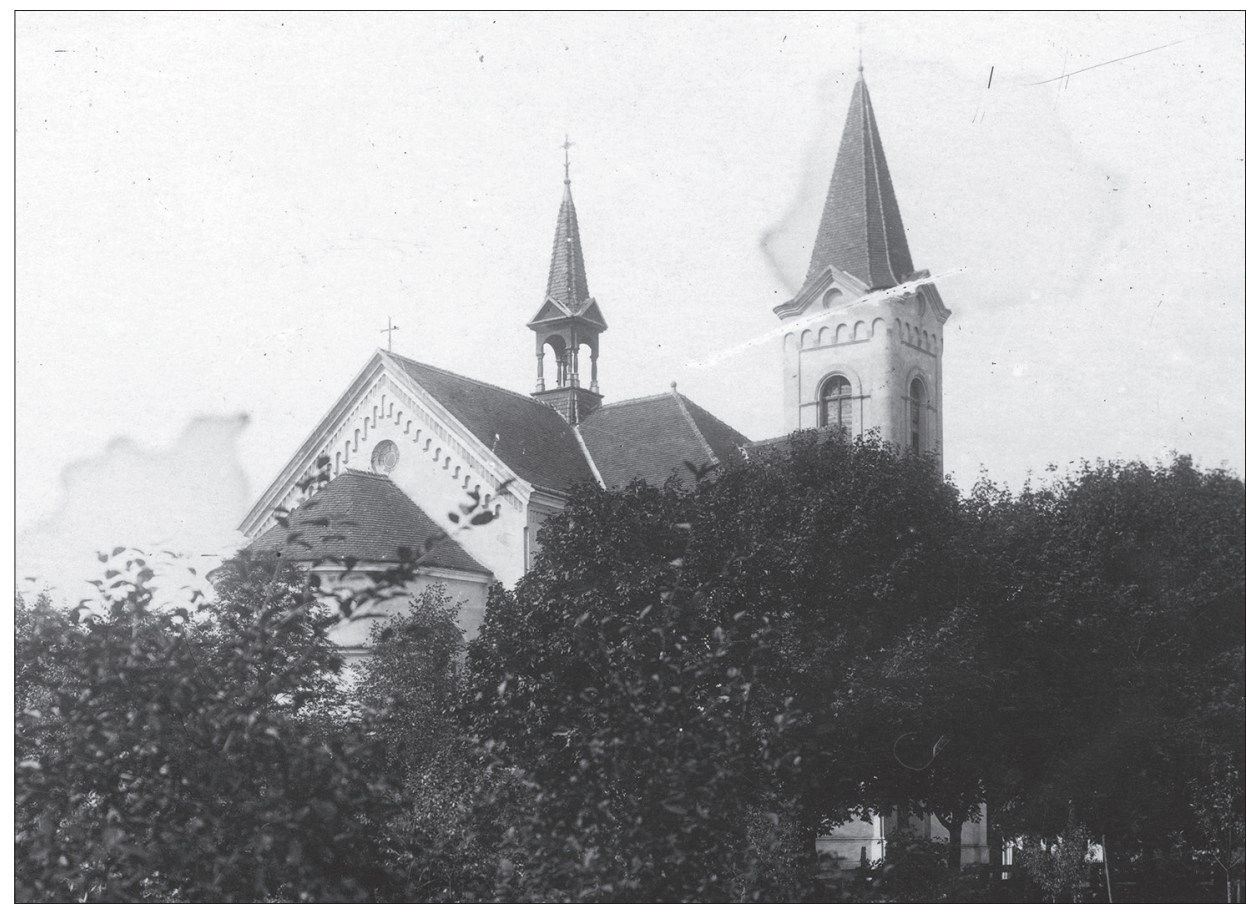

Nisko. Kościół po odbudowie. Narodowe Archiwum Cyfrowe 


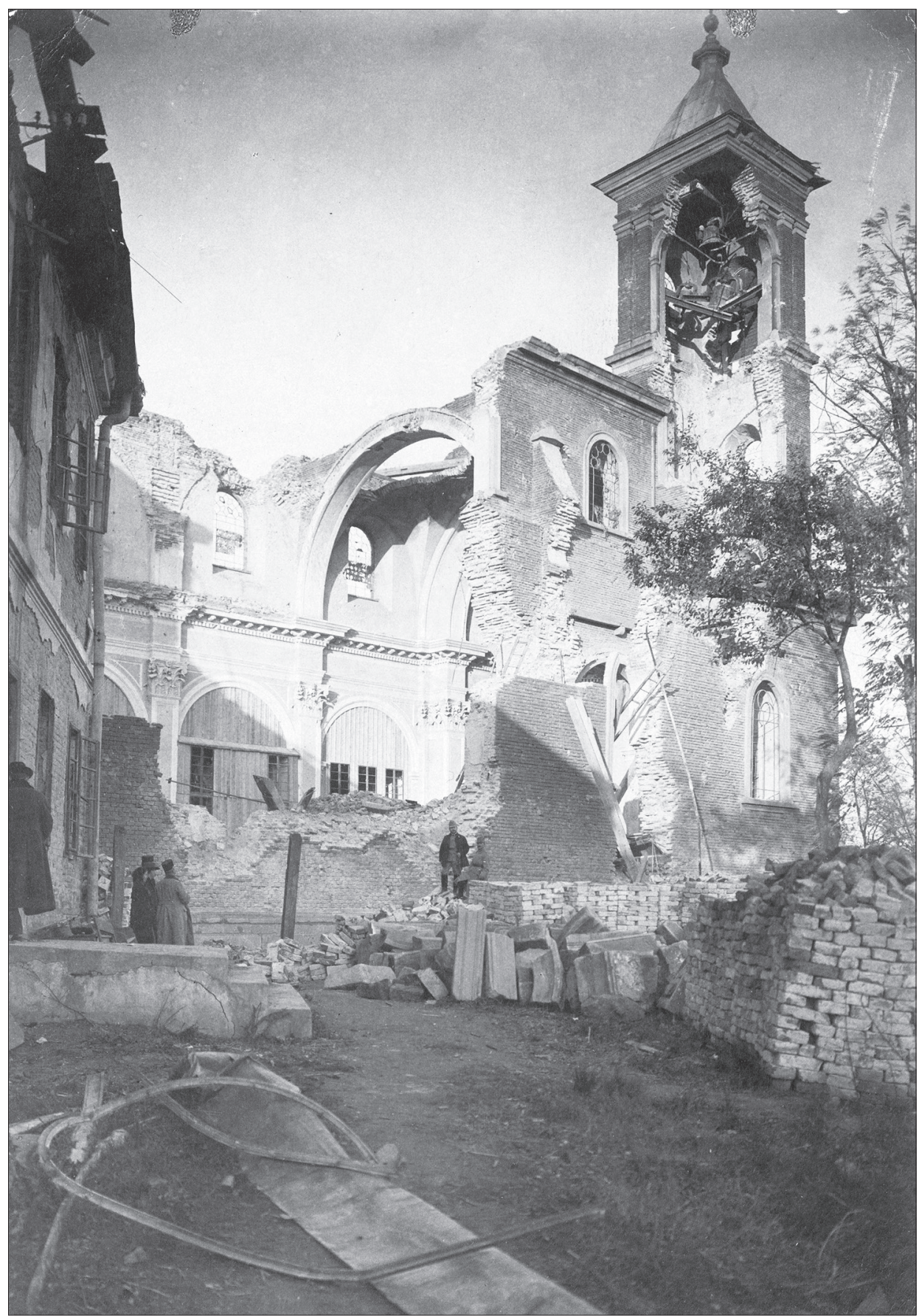

Gorlice. Zniszczony kościół. Narodowe Archiwum Cyfrowe 


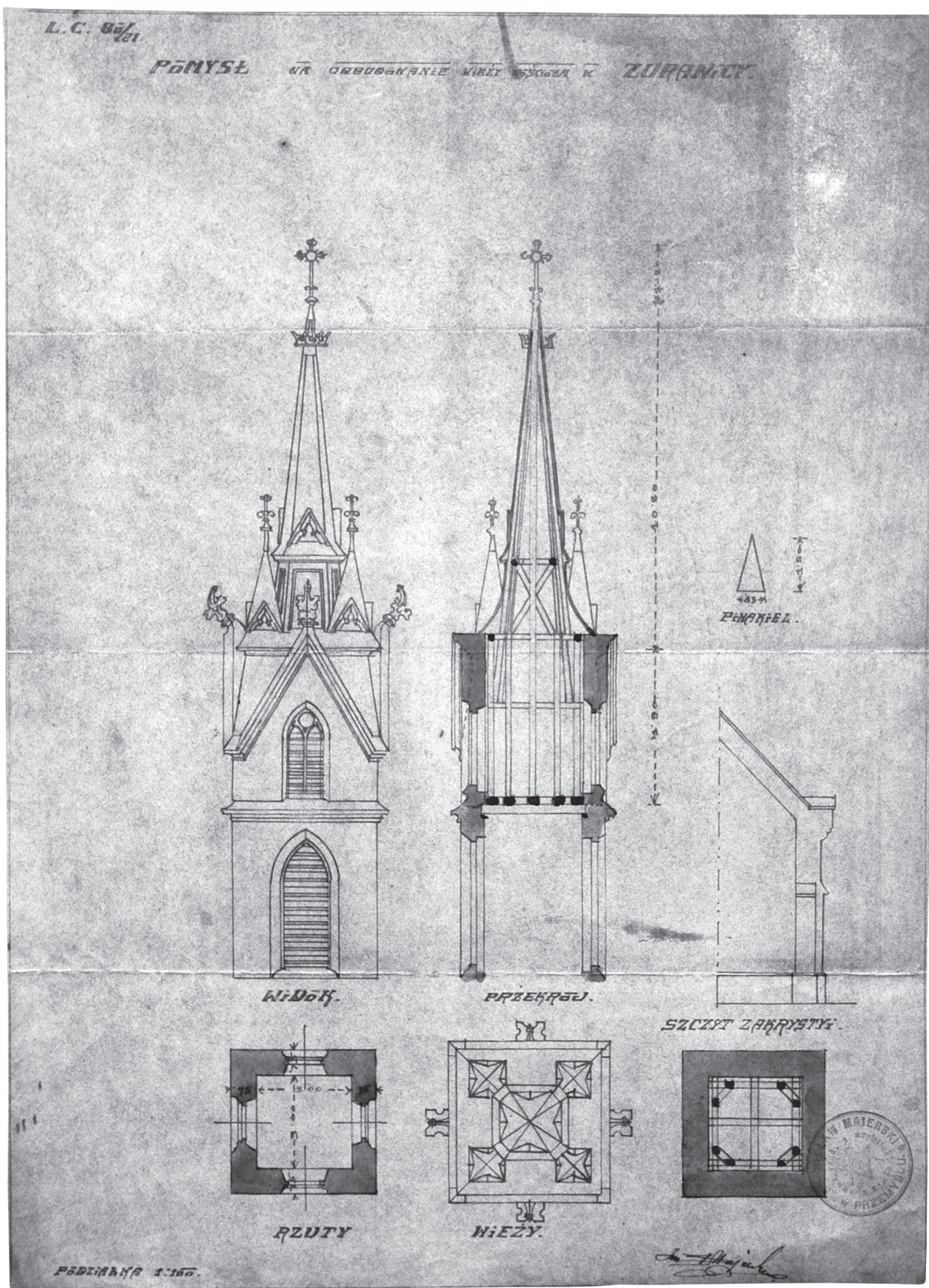

S. Majerski, Plan odbudowy wieży w Żurawicy 1921 r. w zbiorach Muzeum Narodowego Ziemi Przemyskiej, fot. B. Podubny 